Health Policy Review

\title{
Health Care Reform in the United States: Radical Surgery Needed Now More Than Ever
}

Laxmaiah Manchikanti, MD

From: Pain Management Center of Paducah, Paducah, KY

Dr. Manchikanti is Medical Director of the Pain Management Center of Paducah, Paducah, KY, and Associate Clinical Professor of Anesthesiology and Perioperative Medicine,

University of Louisville, Louisville, KY.

Address correspondence: Laxmaiah Manchikanti, M.D. 2831 Lone Oak Road

Paducah, Kentucky 42003

E-mail: drlm@thepainmd.com

Disclaimer: There was no external funding in the preparation of this manuscript.

Conflict of interest: None.

Free full manuscript: www.painphysicianjournal.com
It is often claimed that American health care provides good medical care, but the system through which that care is financed is falling apart. In 1994, Joseph A. Califano, Jr., former Secretary of Health, Education and Welfare reported that the American health care system was in such turmoil, that it needed radical surgery.

Health care in the United States is different from other countries. Health care costs in America have skyrocketed and in 2006 occupied $16 \%$ of the Gross Domestic Product (GDP) with a budget of over $\$ 2$ trillion. Health care expenditures per capita in the United States are higher than 13 other countries utilized in a sample by the Organisation for Economic Co-operation and Development. Estimated spending according to wealth was utilized to measure each country's health care spending in comparison to each other. This measure, including various parameters (undoubtedly some have been missed), largely showed that after adjusting to its higher per capita income levels, the United States spends $\$ 477$ billion - $\$ 1,645$ per capita more on health care than any other peer country.

Many health care proposals have been forwarded since 1965, when Lyndon Johnson succeeded in enacting Medicare. These come from Republicans, Democrats, Independents, physicians, insurers, non-partisan and partisan groups. However, none has been able to provide a guaranteed proposal to fix the health care ills and also provide reasonable coverage.

This manuscript will review escalating national health care expenditures, factors contributing to health care increases, health care systems in many other countries, and various proposals.

Key words: Health care reform, Organisation for Economic Co-Operation and Development, Estimated Spending According to Wealth (ESAW), Centers for Medicare and Medicaid (CMS), universal health care, managed health care reform

Pain Physician 2008; 11:1:13-42 n 1994, shortly after the failure of Hillary Clinton's health care reform, Joseph A. Califano, Jr., former Secretary of Health, Education, and Welfare, who has spent more time than any other American in the trenches of health care reform, author of multiple books related to health care, published Radical Surgery: What's Next for America's Health Care, urging bold action to save the best of American medicine, nourish its genius, contain its costs, and democratize its miracle cures $(1,2)$. In this scathing report about American health care, Califano reported that never has America's health care system been in such turmoil or peril. He said that doctors, nurses, hospitals, managed care companies, and pharmaceutical joints are scrambling into mergers and networks, cooking up new delivery systems, and lining the pockets of 
politicians to get their pieces of the nation's trilliondollar health care business. He also unabashedly stated that in the feeding frenzy, patients are at risk of becoming pawns as doctors are pitted against doctors, hospitals against hospitals, states against each other, the federal government against the states, HMOs against insurers, Republicans against Democrats, the old against the young, the healthy against the sick. Califano described that despite the high cost of treating illness and injury coupled with millions of citizens without insurance, $85 \%$ of Americans who enjoy access to the best medical care in the world and even those who do not have access are worried lest the politicians, even with well-intentioned effort, will screw-up the health care system worse than it is. The only issue that Americans agree upon is that all Americans should have timely access to care, while no one agrees how this will be paid for.

That was 1994. Today, 13 years later, the state of health care in the United States (US) is no better and consequently, the radical surgery that Califano called for is still required.

In 2007, with a health care budget of over $\$ 2$ trillion and estimates that it may approach $\$ 3$ trillion over the next 10 years, Americans are worried and rightfully so that these budgets are considered enormously wasteful, ill-targeted, inefficient, and unfair. Hacker (3) claimed that the US medical care is extremely good, but the system through which that care is financed is extremely bad - and falling apart. Runaway health care costs are an increasingly grave threat, not just to the security of family finances, but also to corporate America's bottom line. The United States spends much more as a share of its economy on health care than any other nation, and yet, all this spending has failed to buy Americans the one thing that health insurance is supposed to provide: health security. The challenge of rising health care costs is not a small issue for Congress, the Administration, the business community, or the public at large.

Orsazg and Ellis $(4,5)$ stated that the long-term fiscal condition of the United States has been largely misdiagnosed. Michael Moore's Sicko has prompted articles on healing our "sick" health care system (6). While we do not find the answer in Moore's movie, as disingenuous and beyond the truth as it is, Sicko is not a careful accounting of the pros and cons of the US health care system, the basic truth of Moore's indictment is undeniable. Health care costs are increasing in all circles at an exponential rate in all geographic regions, and age groups (7).

The main function of a US health care system is to promote health among its citizenry by ensuring that all people have adequate access to healthcare benefits, making certain that the system delivers care of consistently high quality and by achieving all this at a sustainable level of cost (8).

Day in and day out Americans hear how expensive the US health care system is, while at the same time, physicians are complaining about continued cuts and insurance bureaucracy, and hospitals are complaining about shrinking bottom line. A balanced view has never been presented, showing not only the ills of the US health care system, but also a balanced comparison with other health care systems. This manuscript will describe the advantages and benefits of the US health care system; the disadvantages; the cost of US health care compared to other nations; and discussion of various proposals for performing surgery, whether radical or not, and potential consequences to the US health care.

\section{Historical Perspective}

Califano (1) describes in his book Radical Surgery the evolution of health care as a house of surprises. On December 4, 1963, President Lyndon B. Johnson, urging members of the AFL-CIO to support the enactment of Medicare, stated that in 1950 the annual cost of personal health care was $\$ 10.6$ billion and in 1962 had increased to $\$ 28.6$ billion. President Johnson, even in those days, pointed out that the cost of personal health care was increasing on a straight line upward. He believed that Medicare was a low-cost program into which an American worker would put in $\$ 1.00$ a month, his employer would put in $\$ 1.00$ a month of tax deductible money, and the government would put up nothing. In this fashion, the worker could solve his medical cost problems with dignity and not disaster.

Now we know better. Forty-five years after Johnson's postulations with lessons learned from numerous promises, proposals, and political activities, and an understandings of the treacherous course of health care reform, we aren't any better off today than we were in 1963 - if anything we are in much worse shape.

The involvement of government in health care can be traced to World War II, sparking research which produced wonder drugs such as penicillin and dramatic advances in surgery offering people hospital admissions not to ease the pain of dying, but also to be cured. Of course, this created patient's interest in 
access to modern medical care (1). To attract workers, the War Labor Board administering wage and price controls held the line on pay hikes by permitting increases in benefits including health insurance, which became the premier benefit. This was followed by the Taft-Hartley Act of 1947, and eventually leading to the Supreme Court's decision providing unions with the right to negotiate workers' benefits, notably the best of all benefits: health care.

Prior to Medicare, Congress passed the Kerr-Mills Act in 1960, which covered everything from hospital, surgical, and physician care to drugs and false teeth, a special benefit for the poor elderly in the south (1). This was not a successful program, but it provided ammunition for President Lyndon B. Johnson to create Medicare and give birth to Medicaid to help "poor mothers and babies." Medicare and Medicaid provided payment to hospitals including their costs plus a guaranteed percentage, and payment to physicians that were reasonable, customary, and prevailing in their communities, leading to the secondary unexpected consequences of unnecessary waste and self control of prices by the providers. The initial cost of Medicare was expected to be half a billion dollars, it reached $\$ 408.3$ billion in 2006 and is expected to reach $\$ 862.5$ billion in 2016 (9). The enactment of the Medicare Part D Program to provide drug coverage for Medicare recipients by means of enactment of the Medicare Prescription Drug, Improvement, and Modernization Act in 2003 has seen the largest expansion since the inception of Medicare (10).

Starting with Lyndon B. Johnson, every president including George W. Bush, and every candidate running for high office, have sought many ways to reduce health care costs, trying everything from price controls to promoting HMOs and managed care, including diagnosis-related groups (DRGs), and the sustained growth rate (SGR) formula.

\section{Increasing Health Care Costs}

The United States has the highest overall health care expenditure as well as the highest expenditure per capita of any country in the world $(11,12)$. In 2005, the United States spent $\$ 1.9$ trillion, or $16 \%$ of the Gross Domestic Product (GDP) on health care. Figure 1 and Table 1 illustrate the national health expenditures (NHE), showing approximately $\$ 913$ billion in 1993 increasing to $\$ 4.1$ trillion by the year 2016 with the percentage of the proportion of GDP increasing from $13.7 \%$ to $19.6 \%$. While there is no optimal amount

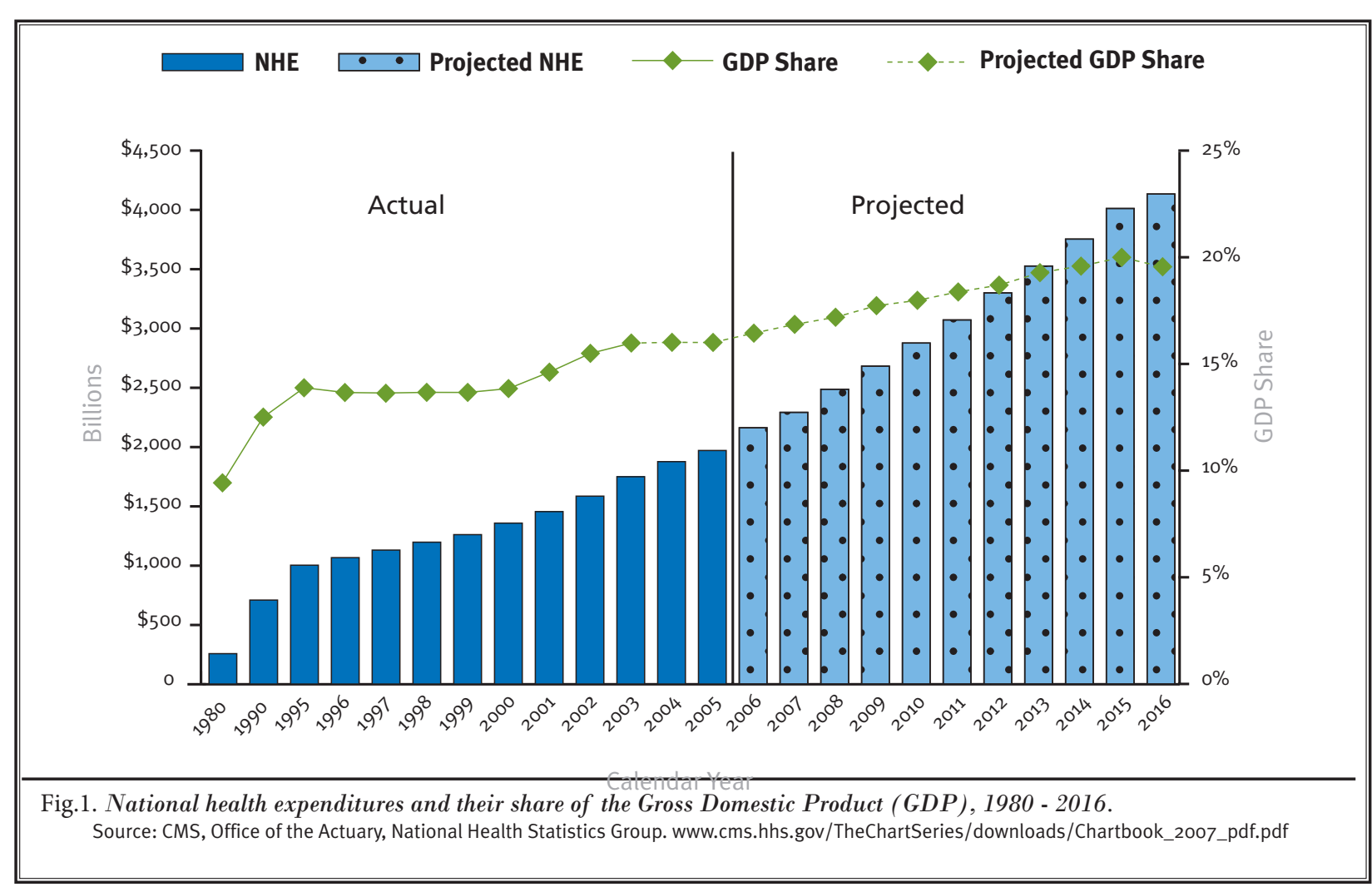


Pain Physician: January 2008; 11:13-42

Table 1. National health expenditures (NHE), by source of funds, amounts, and average annual growth, calendar years 1993-2016

\begin{tabular}{|c|c|c|c|c|c|c|c|}
\hline Spending category & 1993 & 2004 & 2005 & $2006^{\mathrm{a}}$ & $2007^{a}$ & $2011^{\mathrm{a}}$ & $2016^{a}$ \\
\hline NHE (billions) & $\$ 912.6$ & $\$ 1,858.9$ & $\$ 1,987.7$ & $\$ 2,122.5$ & $\$ 2,262.3$ & $\$ 2,966.4$ & $\$ 4,136.9$ \\
\hline Health services and supplies & 853.2 & $1,738.9$ & $1,860.9$ & $1,987.7$ & $2,188.9$ & $2,778.1$ & $3,869.9$ \\
\hline Personal health care & 773.6 & $1,551.3$ & $1,661.4$ & $1,769.2$ & $1,885.3$ & $2,472.6$ & $3,449.4$ \\
\hline Hospital care & 317.2 & 566.9 & 611.6 & 651.8 & 697.5 & 922.3 & $1,287.8$ \\
\hline Professional services & 280.7 & 581.1 & 621.7 & 662.8 & 703.9 & 918.9 & $1,253.2$ \\
\hline Physician and clinical services & 201.2 & 393.7 & 421.2 & 447.0 & 474.2 & 612.9 & 819.9 \\
\hline Other prof. services & 24.5 & 52.6 & 56.7 & 60.9 & 64.9 & 82.7 & 111.0 \\
\hline Dental services & 38.9 & 81.5 & 86.6 & 92.8 & 98.6 & 125.5 & 163.4 \\
\hline Other PHC & 16.2 & 53.3 & 57.2 & 62.0 & 66.2 & 97.9 & 159.0 \\
\hline Nursing home and home health & 87.3 & 157.7 & 169.3 & 179.4 & 190.0 & 239.2 & 322.0 \\
\hline Home health care $^{\mathrm{b}}$ & 21.9 & 42.7 & 47.5 & 53.4 & 57.9 & 78.1 & 111.1 \\
\hline Nursing home care & 65.4 & 115.0 & 121.9 & 126.1 & 132.1 & 161.2 & 210.9 \\
\hline $\begin{array}{l}\text { Retail outlet sales of medical } \\
\text { products }\end{array}$ & 88.4 & 245.5 & 258.8 & 275.2 & 293.9 & 392.1 & 586.4 \\
\hline Prescription drugs & 51.0 & 189.7 & 200.7 & 213.7 & 229.5 & 317.5 & 497.5 \\
\hline Durable medical equipment & 13.5 & 23.1 & 24.0 & 25.2 & 26.3 & 30.5 & 37.6 \\
\hline Nondurable medical products & 23.9 & 32.8 & 34.1 & 36.3 & 38.0 & 44.1 & 51.3 \\
\hline $\begin{array}{l}\text { Program admin. and net cost of } \\
\text { private health insurance }\end{array}$ & 52.8 & 135.2 & 143.0 & 156.8 & 167.4 & 217.9 & 295.7 \\
\hline $\begin{array}{l}\text { Government public health } \\
\text { activities }\end{array}$ & 26.8 & 52.5 & 56.6 & 61.7 & 66.2 & 87.6 & 124.8 \\
\hline Investment & 59.3 & 119.9 & 126.8 & 134.8 & 143.4 & 188.3 & 267.0 \\
\hline Research $^{c}$ & 16.4 & 38.3 & 40.0 & 41.7 & 43.9 & 55.5 & 75.0 \\
\hline Structures and equipment & 42.9 & 81.7 & 86.8 & 93.1 & 99.5 & 132.8 & 191.9 \\
\hline NHE per capita & $\$ 3,468.6$ & $\$ 6,321.9$ & $\$ 6,697.1$ & $\$ 7,092.0$ & $\$ 7,498.0$ & $\$ 9,525.0$ & $\$ 12,782.2$ \\
\hline Population (millions) & 263.1 & 294.0 & 296.8 & 299.3 & 301.7 & 311.4 & 323.6 \\
\hline GDP, billions of dollars & $\$ 6,657.4$ & $\$ 11,712.5$ & $\$ 12,455.8$ & $\$ 13,253.0$ & $\$ 13,955.4$ & $\$ 16,962.8$ & $\$ 21,138.7$ \\
\hline Real NHE ${ }^{\mathrm{d}}$ & $\$ 1,032.4$ & $\$ 1,698.7$ & $\$ 1,763.0$ & $\$ 1,827.7$ & $\$ 1,900.7$ & $\$ 2,266.6$ & $\$ 2,807.5$ \\
\hline Chain-weighted GDP index & 0.88 & 1.09 & 1.13 & 1.16 & 1.19 & 1.31 & 1.47 \\
\hline PHC deflator & 0.81 & 1.16 & 1.20 & 1.24 & 1.29 & 1.50 & 1.84 \\
\hline NHE as percent of GDP & $13.7 \%$ & $15.9 \%$ & $16.0 \%$ & $16.0 \%$ & $16.2 \%$ & $17.5 \%$ & $19.6 \%$ \\
\hline
\end{tabular}

SOURCES: Centers for Medicare and Medicaid Services, Office of the Actuary, National Health Statistics Group; and U.S. Department of Commerce, Bureau of Economic Analysis and Bureau of the Census.

NOTES: Numbers might not add to totals because of rounding. 1993 marks the beginning of the shift to managed care.

a Projected.

b Freestanding facilities only. Additional services are provided in hospital-based facilities and counted as hospital care.

$c$ Research and development expenditures of drug companies and other manufacturers and providers of medical equipment and supplies are excluded from "research expenditures" but are included in the expenditure class in which the product falls. d Deflated using GDP chain-type price index $(2000=100.0)$.

e Personal health care (PHC) chain-type index is constructed from the producer price index for hospital care, nursing home input price index for nursing home care, and consumer price indices specific to each remaining PHC component $(2000=100.0)$.

Adapted from ref. 7 
that the United States should spend on health care - every country makes its own societal choices - global comparisons can highlight potential opportunities for more rational spending (11). Using a sample of 13 Organisation for Economic Co-operation and Development (OECD) countries, a measure called Estimated Spending According to Wealth (ESAW) was developed (11). This measure adjusts health care spending according to GDP per capita and is anchored in the fact that countries spend more on health care or any good or service as their prosperity increases. However, sadly, they concluded that after adjusting to its higher per capita income levels, the United States spends some $\$ 477$ billion - \$1,645 per capita - more on health care than any other peer countries (11). An international comparison of health care costs from 1960 to 2004 as illustrated in Fig. 2 shows that the United States spent a higher share of GDP spent on health than the OECD median for the past 4 decades $(12,13)$.
Figure 3 illustrates increase of per capita expenses from $\$ 1,067$ in 1980 to $\$ 6,697$ in 2005 and are expected to increase to $\$ 12,782$ by $2016(7,12,13)$. In contrast, as illustrated in Fig. 4, per capita spending on medical services in Canada, France, Germany, and Japan have been lower than in the United States $(12,13)$.

Figure 5 illustrates that overall growth of health spending over the last decade, which was lower in OECD countries than in prior decades including the US. However, in the United States, both the public and private sectors share of health spending has increased, while the share from out-of-pocket spending has declined over the last several decades as illustrated in Fig. 6. Further, over the last two decades, private coverage has declined and public coverage (mostly Medicaid) has increased.

Overall, in the United States, the proportion of uninsured has grown from $10 \%$ in 1980 to $18 \%$ in 2004 . Medicaid and other government services have grown

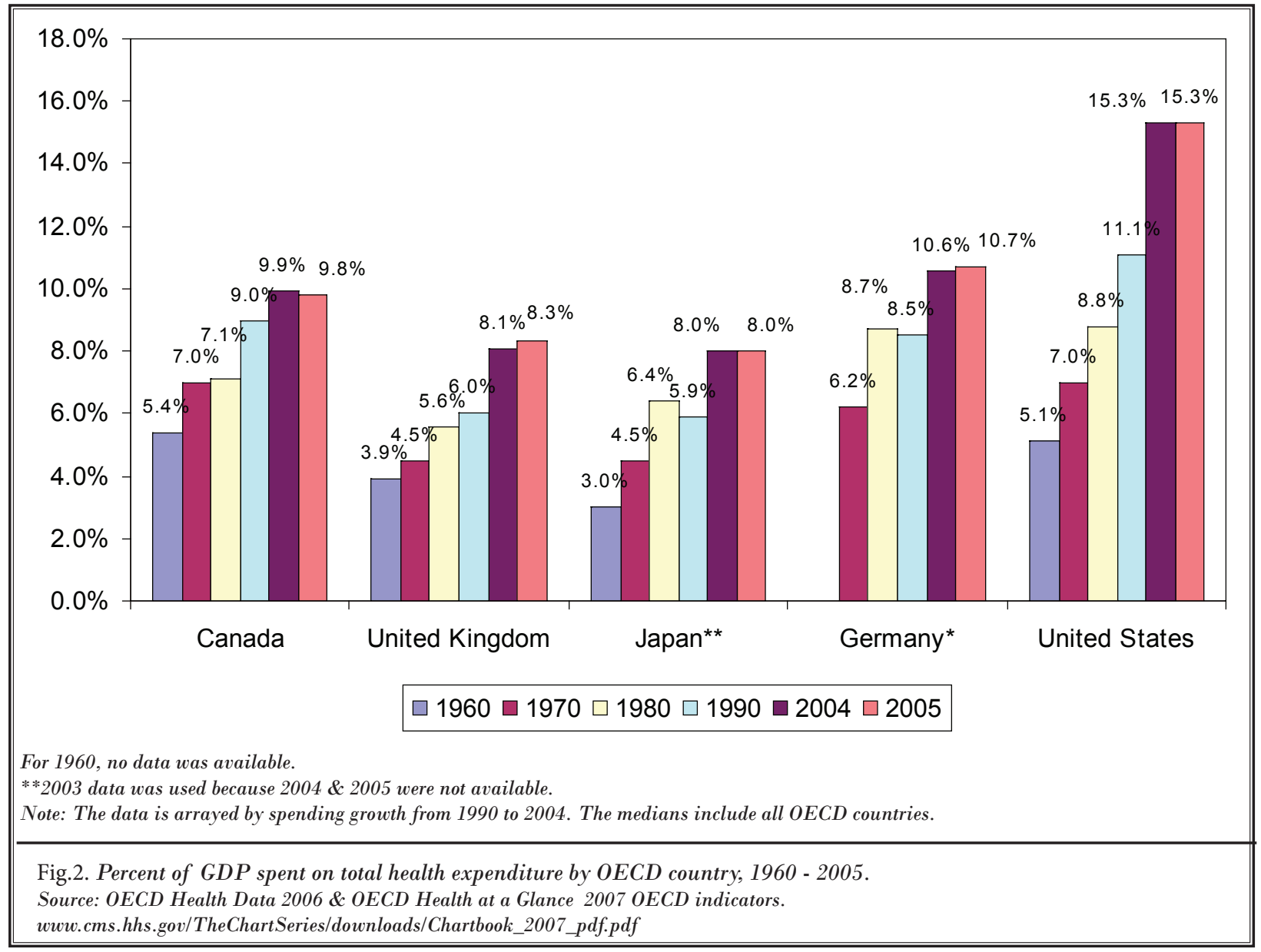



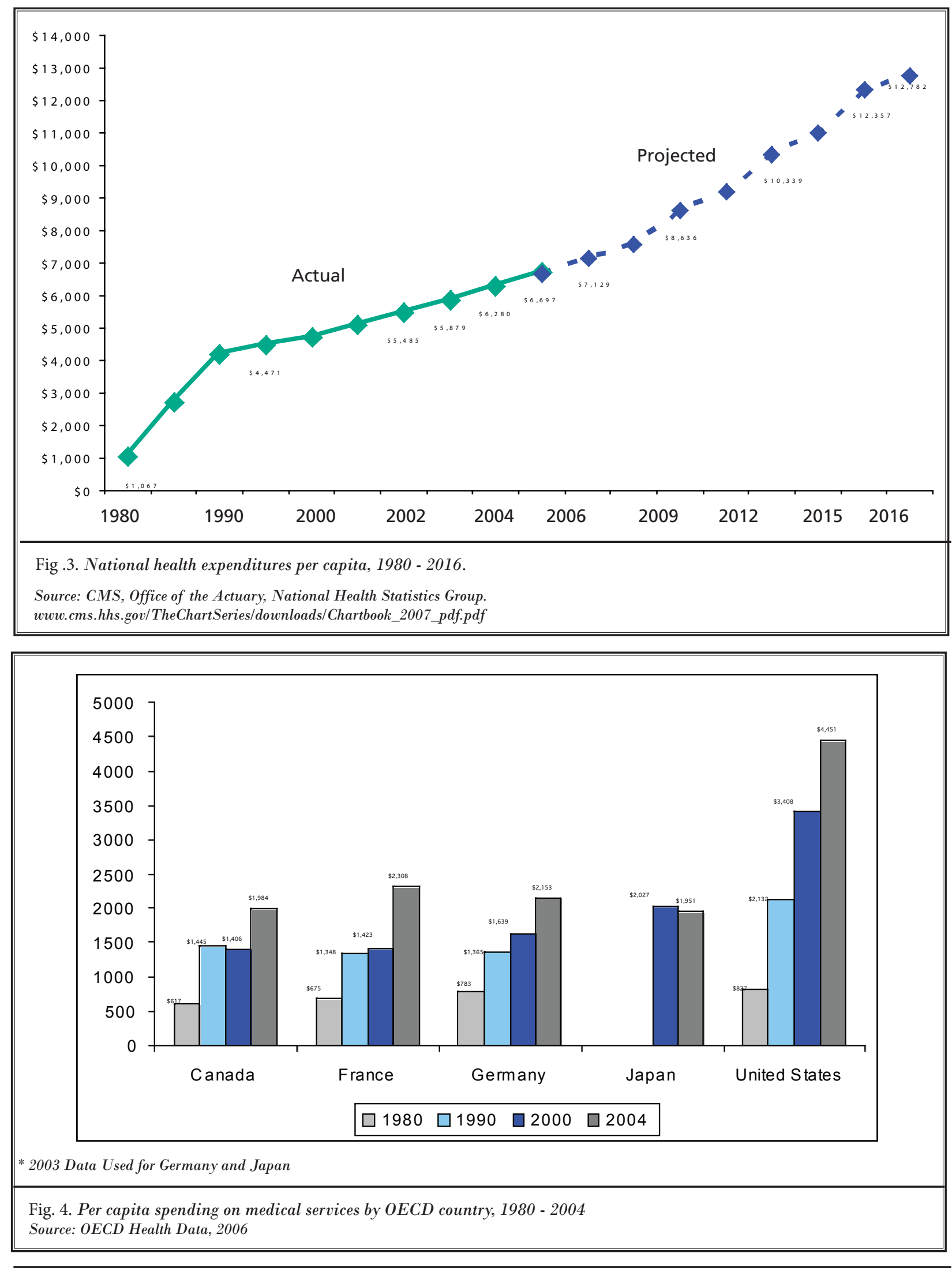


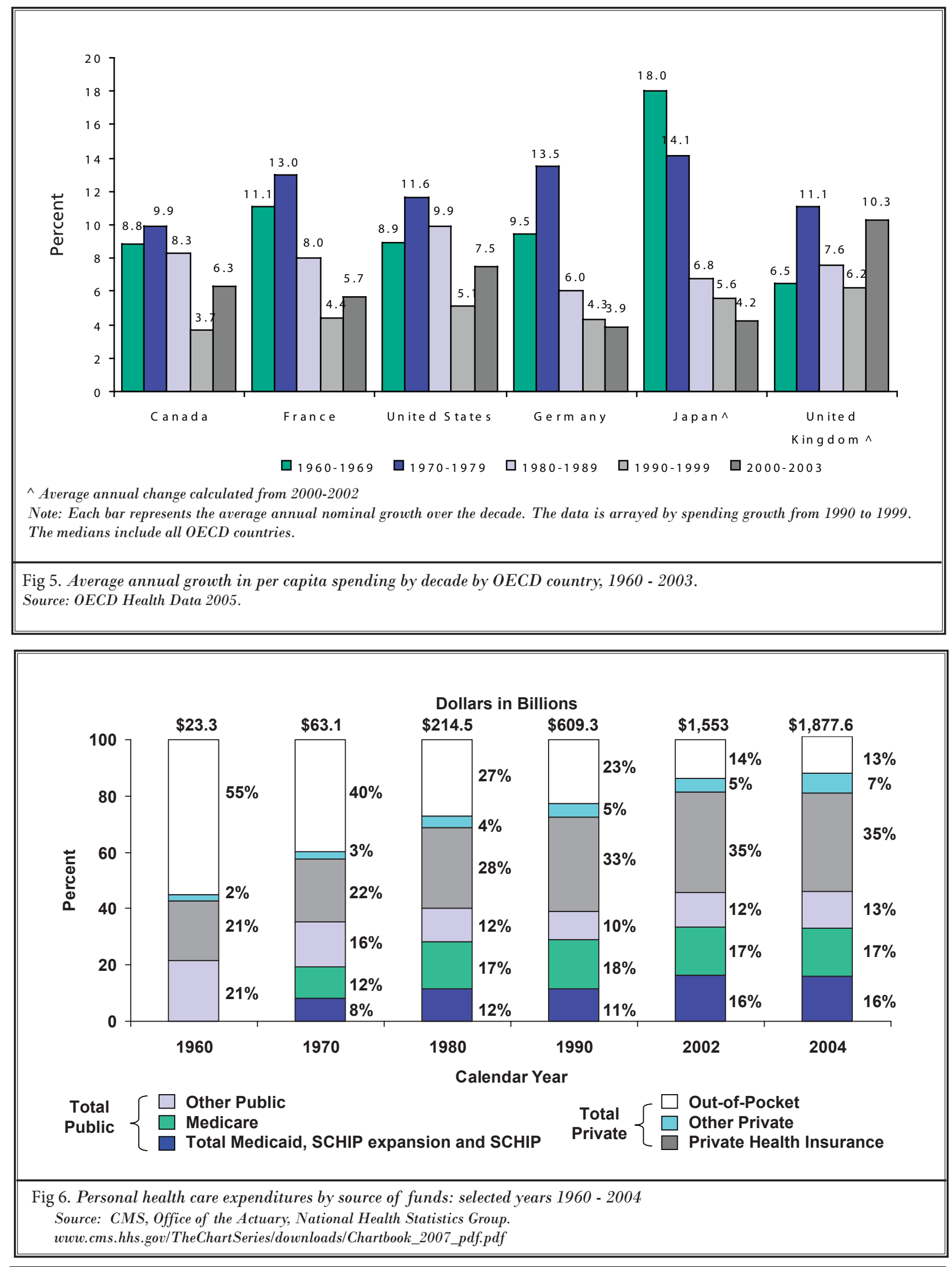


from $15 \%$ to $18 \%$, and any private coverage has declined from $83 \%$ to $69 \%$ (Fig. 7). Personal health care expenditures by type of service from 1960 to 2003 are illustrated in Figure 8. While the share of hospital, phy- sician, nursing home, and other expenditures changed slightly, the share of health spending on prescription drugs has grown since 1980. However, health spending remains highly concentrated on a small proportion of

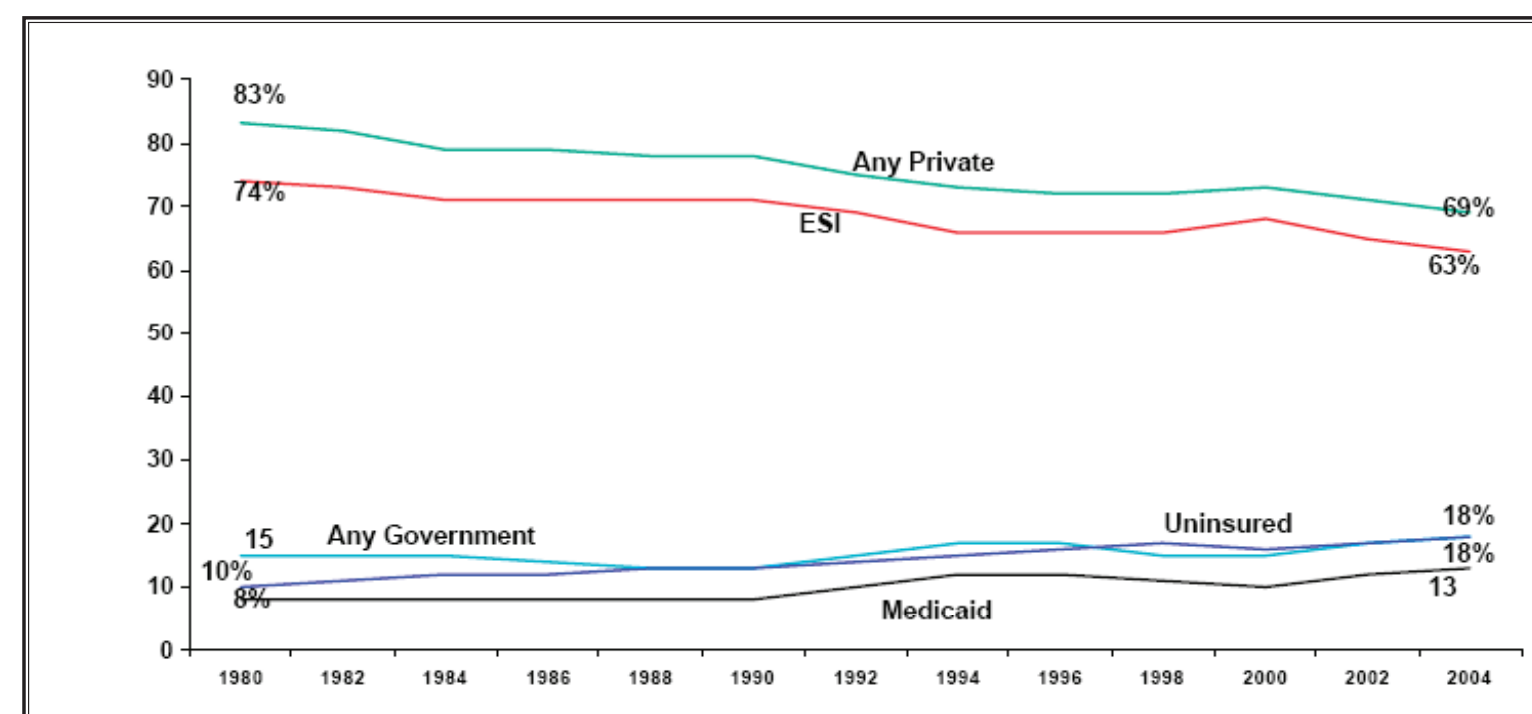

Notes: ESI - Employer Sponsored Insurance. Any Private includes ESI and individually purchased insurance. Any government includes Medicare for the disabled population.

Fig 7. Health insurance coverage for the under 65 population, $1980-2004$.

Source: www.cms.hhs.gov/TheChartSeries/downloads/Chartbook_2007_pdf.pdf

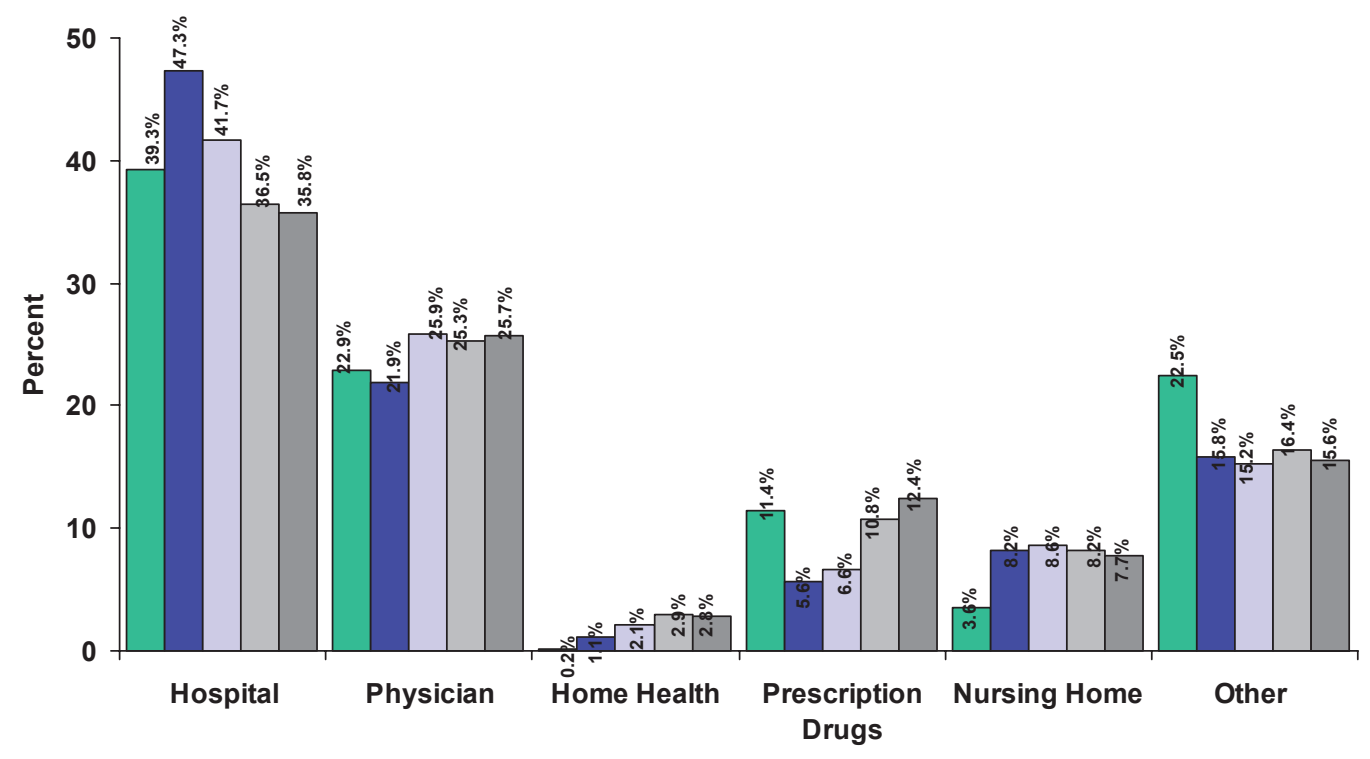

$\square 1960 \square 1980 \square 1990 \square 2000 \square 2003$

Fig 8. Personal health care expenditures by type of service, $1960-2003$.

Source: www.cms.hhs.gov/TheChartSeries/downloads/Chartbook_2007_pdf.pdf 
the population. The top $1 \%$ of the population account for about $25 \%$ of all health spending (12), which has decreased from $28 \%$ in 1987 to $22 \%$ in 2002 . Ninetyseven percent of health care expenditures are spent on the top $50 \%$ of the population, whereas approximately half of all expenditures are spent on the top $5 \%$ and two-thirds of the expenditures are spent on the top $10 \%$. In other countries it appears that inpatient spending is greater than outpatient spending, whereas, in the United States, outpatient spending is almost double the inpatient spending.

Figure 9 illustrates the national health spending by source of funds by OECD countries in 2003. The source of funding varies significantly by country with out-of-pocket spending ranging from $8 \%$ to $18 \%$ of health spending, with the United States at about the median. In all other countries with some type of national health care system, their social security schemes or general government funding was substantially higher compared to the United States.

\section{Accounting For The Cost}

Per capita spending in the United States is the highest among OECD countries (11-13). The expenditures per capita in the United States were $\$ 5,635$ on health care in 2003, whereas based on the analysis of ESAW it should be $\$ 3,990$ per capita. Consequently, the United States spent $\$ 1,645$ per capita more than would have been expected. Overall it was calculated that the United States spends $\$ 477$ billion more than would be predicted by the ESAW regression line.

Measured in terms of the share of the GDP, the United States spent $15 \%$ on health care in 2003 compared with the OECD median of $8.5 \%$. In 1960, the United States spent $5.2 \%$ of GDP on health care; by 2004 that number had risen to $15.9 \%$, and it is forecasted that by 2030 spending on health care will be $25 \%$ of the US GDP.

The US health care system is intrinsically more expensive. The key explanation for higher US health care costs based on the analysis of seven categories of health care spending and comparing them to 13 OECD

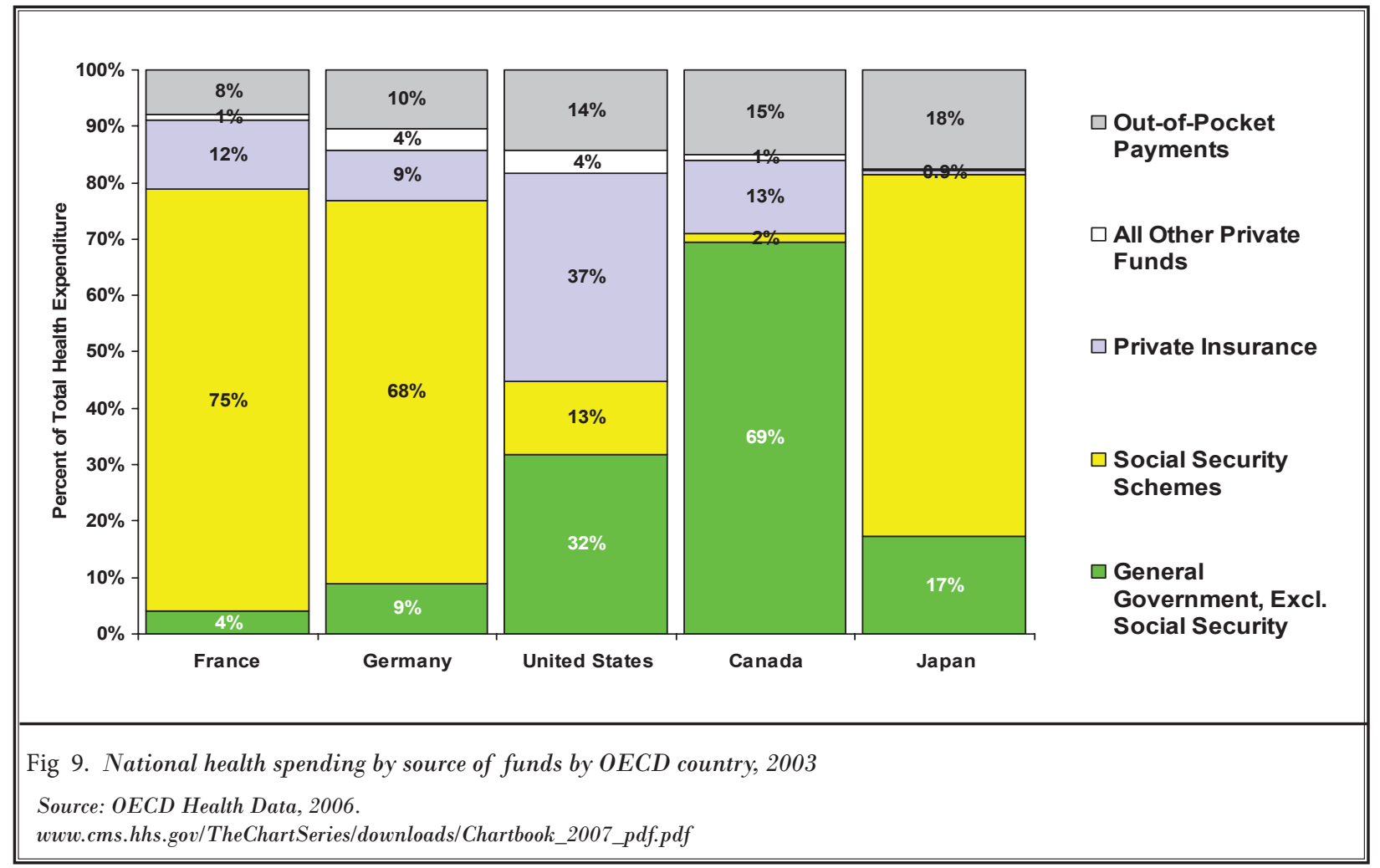


countries (11), related to different segments of health care payments to providers/suppliers.

A summary of the results revealed that in 5 out of the 7 spending categories - hospital care, outpatient treatment, drugs, health administration and insurance, and public investment in health, the United States is above ESAW, spending more on health care than would be expected given its wealth. In absolute terms, the highest discrepancy was noted in hospital care ( $\$ 224$ billion), followed by outpatient care ( $\$ 178$ billion). However, the largest discrepancy was the category of administration of the health care system, on which the United States spends 6 times more per capita than its peer OECD countries ( $\$ 412$ vs $\$ 72$ ), almost a quarter of excess spending in the United States.

The United States currently spends \$1,929 per capita on hospital care compared with $\$ 1,119$ per capita predicted by ESAW. Hospitals captured the largest share of health care spending (Fig. 10) and have been a major component of the health care explosion in the United States $(14,15)$. Spending on hospital care accounts for $\$ 224$ billion or $41 \%$ of the total gap between US health care spending and what would be predicted by ESAW.
Outpatient treatment centers are the next largest category which includes physician services, dental services, and other outpatient medical facilities that are not owned by hospitals. Ambulatory surgical centers, diagnostic imaging centers, mental health clinics, and non-physician offices are all included in this category. Currently, $\$ 1,678$ per capita is spent on outpatient care in the United States compared with a predicted amount of $\$ 1,066$. This corresponds to a total spent above ESAW of $\$ 178$ billion or $37 \%$ of the total additional health care spending in the United States compared to ESAW predictions (11).

Combined, hospital care and physician-staff outpatient facilities account for an additional spending above ESAW of $\$ 371$ billion with the largest discrepancy of $\$ 147$ billion attributed to operational costs and support functions above ESAW (11). For hospitals, the United States performs 88 procedures per year per 1,000 population compared with the OECD average of 75 , contributing to higher health care spending in the United States. Some of the discrepancies are explained by coronary artery bypass and angioplasty which are performed more than 4 times as frequently in the United States as in the United

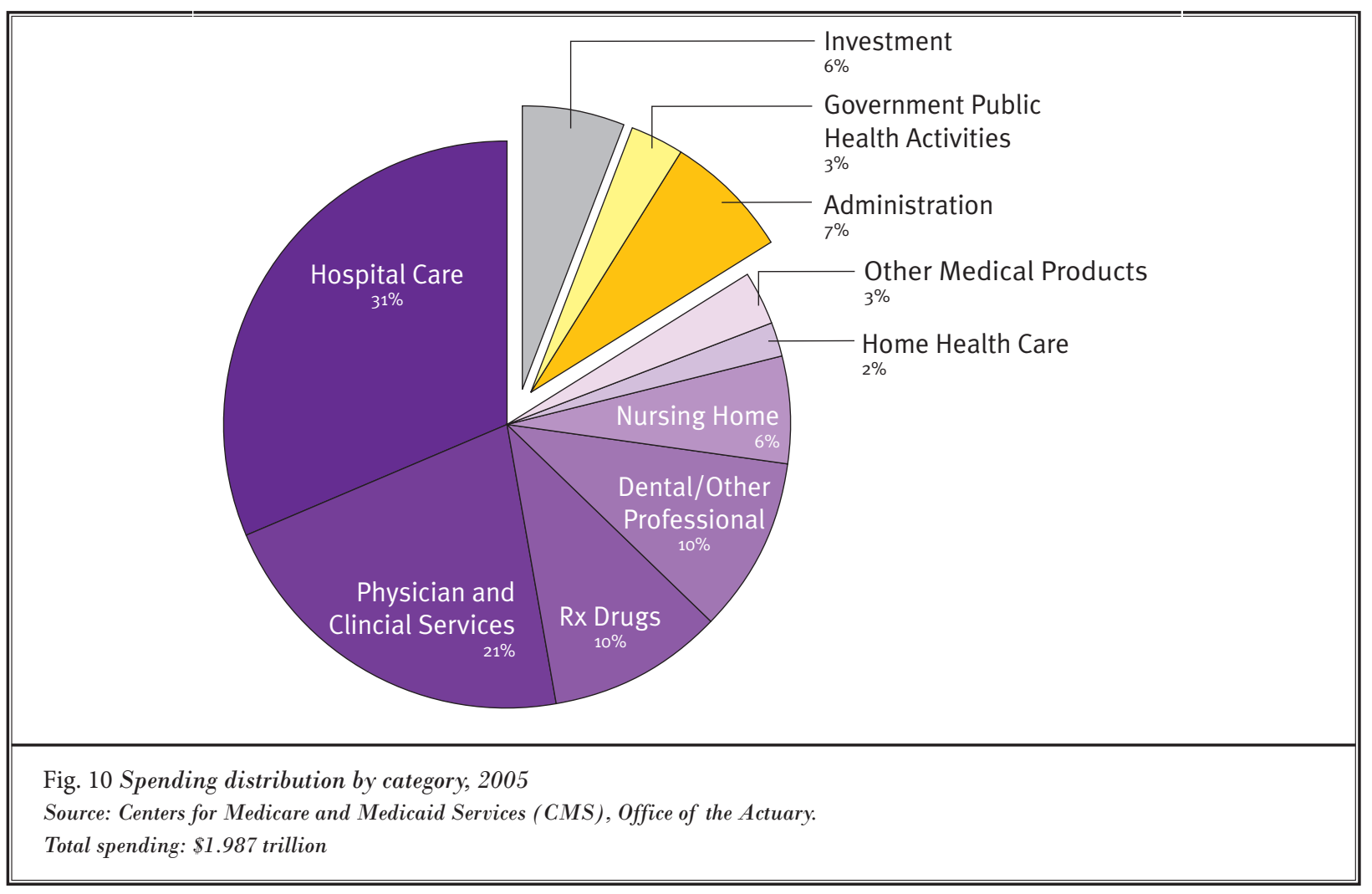


Kingdom (UK). Overall, hospitals in the United States are left with a proportionately higher mix of costly procedures in complicated medical patients which necessitate higher operational expenses. This study also explains the higher costs for outpatient centers by a combination of inefficient and subscale operations and a lack of value consciousness on the part of the consumers and providers, even though these centers are approximately $20 \%$ to $30 \%$ less expensive than hospitals (11). This evaluation questions the value of outpatient centers and the proposition that they produce lower costs, increase access and provide better quality. The entire concept is based on the premise that physicians can hold equity in the medical service centers in the United States despite the rules ostensibly designed to prevent abuses under Stark regulations as well as Anti-Kick Back Statutes (10, 16-19). Further, this study shows that physicians' total compensation contributes an additional $\$ 58$ billion above the ESAW of which $\$ 50$ billion arises from their remuneration from salaries, professional fees, or a combination of these, and $\$ 8$ billion is income from equity stakes at outpatient centers (11). This analysis also showed that physicians' compensation is, on average, 4 times the GDP per capita for specialists and 3.2 times for generalists in other OECD countries. However, in the United States, these figures rise to 6.6 and 4.2, respectively.

Compensation for nurses and other clinic professionals is $\$ 50$ billion above the ESAW in the United States. Additional spending claimed on labor and is blamed on staffing patterns, increased acute care needs in hospitals, and higher ratios of clinicians to patients. The United States employ 9.5 nurses per 1,000 acute care bed days compared with the OECD average of 7.1 nurses. Further, in inpatient medical and surgical facilities, staffing ratios are usually 1 nurse for 6 to 8 patients compared with 1 nurse per 10 to 12 patients in Europe. The salaries of nurses in the United States, however, are in line with OECD countries, around 1.3 times the GDP per capita.

Non-drug supplies account for $\$ 18$ billion of spending above ESAW. The United States spends 54\% above ESAW on the top 5 inpatient devices - defibrillators, pacemakers, coronary stents, hip implants, and knee implants - when compared with Europe and Japan. Higher volume as well as prices account for additional spending. Consequently, the wealth-adjusted cost of a knee implant is $32 \%$ higher and a hip implant $65 \%$ higher than the average in other countries.
Provider profits and taxes contribute another $\$ 75$ billion to the United States' spending. Public data sources illustrate that $\$ 27$ billion of the profit generated by US health care providers can be attributed to higher returns on investment. Additional operational costs account for another $\$ 147$ billion of US health care spending above ESAW, which includes all non-clinical labor, operational expenses, rent and lease, and insurance against medical malpractice. In addition, the United States spent $\$ 412$ per capita on health care administration and insurance in 2003 - nearly 6 times as much as the OECD average. The unique multiple-payor system, differences in insurance regulations across states, and the complexities of administering Medicare, Medicaid, and private insurance products are responsible for additional administrative expenses. This total, however, excludes the additional administrative burden of the multi-payor structures and insurance products on hospitals and outpatient centers, which is accounted for under providers' operational costs and extra costs incurred by employers because of the need for robust human resource departments to administer health care benefits. Overall, $\$ 98$ billion is spent on administration above ESAW of which $\$ 84$ billion can be traced to private stakeholders, and the remaining $\$ 14$ billion to public-sector stakeholders.

However, the accounting for health care as described above may not tell the entire story. First, health care spending was adjusted according to the GDP per capita and per capita income levels without consideration for taxes and unemployment rate. In fact, for the French, taxes constitute $44 \%$ of the GDP compared with $26 \%$ in the United States coupled with an unemployment rate of $9 \%$ in France compared to less than $5 \%$ unemployment in the United States (2023). Further, the regulatory burden of health care on the US economy is sizable, and the health industry is often viewed as among the most heavily regulated sector of the US economy, which incurred regulatory costs that may exceed \$1 trillion (24) - an unhealthy trend. Using a "bottom-up" approach, it is estimated that the total cost of health services regulation exceed $\$ 339$ billion. This figure takes into account the regulation of health facilities, health professionals, health insurance, drugs and medical devices, and the medical tort system. In addition, this approach allows for a reasonable calculation of some "tangible goods" of regulation, namely $\$ 170$ billion in provided health care benefits. From these figures, it can be seen that the costs of health care services regulation which 
amounts to $\$ 169$ billion outweighs those of provided goods by 2 to 1 and these cost the average household over $\$ 1,500$ per year. Further, the high cost of health services regulation is responsible for more than 7 million Americans lacking health insurance (i.e., 1 in 6 of the average daily uninsured). In addition, it has been contended that the annual net cost of health services regulation dwarfs other costs imposed by government intervention in the health care sector, exceeding the annual consumer expenditures on gasoline and oil in the United States. It has been noted that these costs are twice that of the annual output of the motion picture and sound recording industries (24). It has been proposed that the need and possible venues for reducing or eliminating these excess costs is an urgent matter of policy that could be achieved through medical tort reform, which in essence offers the most promising target for regulatory cost savings, enhanced by FDA reform, selected access-oriented health insurance regulations (e.g., mandated health benefits), quality oriented health facilities, and revision of accreditation and licensure regulations. Such reforms, it is estimated, could save approximately $20 \%$ of the $\$ 2$ trillion health care budget and would represent an important step towards improving the system, along with increased efficiency and cost-effectiveness of health care practices in the United States.

An alternative view of health care expenditures with savings of $20 \%$ which will cure the health care budget may not be a reality, but a possibility. In addition, in the opposite direction, eliminating Medicare fraud alone could reduce Medicare spending by approximately $\$ 60$ billion or $17.7 \%$ of the 2006 Medicare budget of $\$ 338$ billion. However, reduced regulation and increased levels of fighting Medicare and insurance fraud will not go hand in hand.

Finally, administrative costs of profits, taxes, and operational costs exceed $\$ 220$ billion for US health care spending, and the United States spent $\$ 412$ per capita on health care administration and insurance in 2003 - nearly 6 times as much as the OECD average. Thus, the $\$ 1,645$ per capita ( $\$ 477$ billion) by which the United States exceeds the other OECD countries may be saved by the elimination of health services regulation costs of $\$ 339$ billion, $\$ 75$ billion in provider profits and taxes, $\$ 147$ billion in operational costs, and over $\$ 412$ per capita ( $\$ 119$ billion) on health care administration and insurance.

\section{Comparison Of Health Care Experiences Across The Globe}

The 2007 Commonwealth Fund International Health Policy Survey interviewed adults in 7 countries with a focus on access, primary care, coordination, and safety. The 7 countries included Australia, Canada, Germany, the Netherlands, New Zealand, the United Kingdom, and the United States (25). However, this survey did not include access to specialty services. The survey is based on the concept that comprehensive and well-integrated primary care is associated with better outcomes and lower costs $(26,27)$. The study fundamentally is based on the evidence and the concept that the development of a primary care systems that serve as medical homes has emerged as a conceptual approach to improving the US system performance (28). Discrepancies emerging from this survey include that while the United States spent by far the highest share of national income on health care, it is the only country that leaves a high percentage of its population uninsured or poorly protected in the event of illness. Furthermore, of all these countries, the United States has the smallest share of general practice and family practice physicians, thus relying extensively on internal medicine and pediatrics for primary care. Ironically, in other countries also, the percentage of primary care physicians has been declining (29).

Sampling and study design of this study may deserve some attention. The survey consisted of interviews with representative samples of adults aged 18 and older in 7 countries with the Commonwealth Fund the core study in partnership with the Health Council of Canada, the Dutch Ministry of Health in the Netherlands, and the German Institute for Quality and Economic Efficacy in Health Care. Funding was from different sources and interviews were conducted by telephone Thus, the vast differences and with the data gathering involvement of their own governments who tend to keep their health care system in a better light, questions of validity arise.

The results of this survey described the United States as the most expensive country for health care in 2007 with $16 \%$ of the GDP or $\$ 6,697$ per person spent on health care as shown in Table 2. Primary care practices with financial incentives for quality were highest in the United Kingdom with $95 \%$ followed by $79 \%$ in New Zealand and the lowest in the United States with $30 \%$. The percent of uninsured was $0 \%$ to less than 
$2 \%$ in all the countries except the United States where it was equal to health care expenditures as a percentage of the GDP, i.e., $16 \%$.

Table 3 illustrates the 2007 results of health system views, confidence, and cost among adults in 7 countries. Adults in the US held the most negative views and were the most likely to report affordability concerns, in contrast to the Dutch public with its positive views, including high levels of confidence in the quality and accessibility of care and low levels of costrelated concerns. Public views, according to this survey, in Canada and New Zealand have grown steadily more positive in the past decade and are now comparable to views in Australia and the United Kingdom compared to the United States $(25,30)$. German adults ranked just behind the US adults in negatives and adults from New Zealand and the United Kingdom expressed the least confidence that they will receive the most effective medications or medical technology if they become ill.

There were marked differences across the countries in waiting times among those needing elective surgery, with German and US adults reporting the most rapid access, in contrast to Canadian and British adults, with the longest waits. In Canada and the United Kingdom, $8 \%$ of the adults reported waiting a year or more and $15 \%$ reported waiting 6 months or more for elective surgery, even though in other countries waits of a year or more were rare. In contrast, patients in the United States reported rapid access to elective surgery. One-fifth of US adults reported serious problems paying medical bills in the past year - more than double the rates in the next highest countries. In contrast, Dutch and British adults, with comprehensive coverage, reported lower out-of-pocket costs and access concerns related to costs. Concerns in

Table 2. Overview: Health spending and insurance systems in seven countries, 2007.

\begin{tabular}{|c|c|c|c|c|c|c|c|}
\hline & AUS & CAN & GER & NET & $\mathbf{N Z}$ & UK & US \\
\hline \multicolumn{8}{|l|}{ National health spending } \\
\hline Per capita (U.S. \$PPP) ${ }^{\mathrm{a}}$ & $\$ 3,128$ & $\$ 3,326$ & $\$ 3,287$ & $\$ 3,094$ & $\$ 2,343$ & $\$ 2,724$ & $\$ 6,697$ \\
\hline Percent of GDP ${ }^{\mathrm{a}}$ & $9.5 \%$ & $9.8 \%$ & $10.7 \%$ & $9.2 \%$ & $9.0 \%$ & $8.3 \%$ & $16.0 \%$ \\
\hline \multicolumn{8}{|l|}{ Primary care role, information capacity } \\
\hline Patients required to register & No & No & No & Yes & Yes & Yes & No \\
\hline Referral required for specialist $\mathrm{t}^{\mathrm{b}}$ & Yes & No & No & Yes & Yes & Yes & No \\
\hline \multicolumn{8}{|l|}{ Percent of primary care practices with ${ }^{c}$} \\
\hline Any financial incentive for quality & $72 \%$ & $41 \%$ & $43 \%$ & $58 \%$ & $79 \%$ & $95 \%$ & $30 \%$ \\
\hline Electronic medical records & $79 \%$ & $23 \%$ & $42 \%$ & $98 \%$ & $92 \%$ & $89 \%$ & $28 \%$ \\
\hline \multicolumn{8}{|l|}{ Insurance } \\
\hline Percent uninsured & $0 \%$ & $0 \%$ & $<1 \%$ & $<2 \%$ & $0 \%$ & $0 \%$ & $16 \%^{\mathrm{d}}$ \\
\hline Comprehensive national minimum benefit package & Yes & Yes & Yes & Yes & Yes & Yes & No \\
\hline Prescription drugs: core benefit & Yes & No & Yes & Yes & Yes & Yes & No \\
\hline Primary care cost sharing for visit & Yes $^{\mathrm{e}}$ & No & Yes & No & Yes & No & Yes \\
\hline
\end{tabular}

SOURCES: See below.

NOTES: PPP is purchasing power parity. GDP is gross domestic product.

a All countries but the United States: data for 2005 and 2004, from Organization for Economic Cooperation and Development, OECD Health Data 2007 (Paris: OECD, July 2007). United States: data for 2005, from A. Caitlin et al., "National Health Spending In 2005: The Slowdown Continues," Health Affairs 26, no. 1 (2007): 142-153.

$b$ Canada does not require but has incentive to discourage self-referral.

c 2006 Commonwealth Fund International Health Policy Survey of Primary Care Physicians.

d March 2007 census; uninsured at a point in time; including those with any time uninsured increases to 25 percent.

e Majority of general practices "bulk bill" and eliminate patient cost sharing.

Adapted from Ref. 25 
Pain Physician: January 2008; 11:13-42

Table 3. Health system views, confidence, and cost among adults in 7 countries, 2007.

\begin{tabular}{|c|c|c|c|c|c|c|c|}
\hline & AUS & CAN & GER & NET & $\mathbf{N Z}$ & UK & US \\
\hline Unweighted $\mathrm{N}$ & 1,009 & 3,003 & 1,407 & 1,557 & 1,000 & 1,434 & 2,500 \\
\hline \multicolumn{8}{|l|}{ Overall health system views } \\
\hline Only minor changes needed, system works well & $24 \% \%^{c, d, g}$ & $26 \% \%^{c, d, g}$ & $20 \%$ d,effg & $42 \% \%^{\mathrm{ef}, \mathrm{g}}$ & $26 \%^{\mathrm{g}}$ & $26 \%^{\mathrm{g}}$ & $16 \%$ \\
\hline Fundamental changes needed & $55^{\mathrm{b}, \mathrm{d}, \mathrm{g}}$ & $60^{c, \mathrm{~d}, \mathrm{e}, \mathrm{g}}$ & $51^{\mathrm{e}, \mathrm{f}}$ & $49^{e, f}$ & $56^{\mathrm{g}}$ & $57^{\mathrm{g}}$ & 48 \\
\hline Rebuild completely & $18^{\mathrm{b}, \mathrm{c}, \mathrm{d}, \mathrm{g}}$ & $12^{c, \mathrm{~d}, \mathrm{f}, \mathrm{fg} g}$ & $27^{\mathrm{d}, \mathrm{e}, \mathrm{fg}}$ & $9^{g}$ & $17^{\mathrm{g}}$ & $15^{\mathrm{g}}$ & 34 \\
\hline \multicolumn{8}{|l|}{ Confident that you will get high-quality, safe care } \\
\hline Very confident & $34^{\mathrm{b}, \mathrm{c}, \mathrm{d}, \mathrm{f}}$ & $28^{\mathrm{cd}, \mathrm{dg}}$ & $24^{\mathrm{d}, e, \mathrm{f}, \mathrm{g}}$ & $59^{\mathrm{e}, \mathrm{fg} g}$ & $30^{\mathrm{g}}$ & $28^{\mathrm{g}}$ & 35 \\
\hline Somewhat confident & $46^{\mathrm{b}, \mathrm{d}}$ & $52^{\mathrm{d}, \mathrm{g} g}$ & $50^{\mathrm{d}, \mathrm{d} g \mathrm{~g}}$ & $35^{\mathrm{e}, \mathrm{fg}}$ & 48 & 44 & 44 \\
\hline Not very/not at all confident & $20^{c \mathrm{~cd}, \mathrm{f}}$ & $19^{\mathrm{cd,}, \mathrm{f}}$ & $26^{\mathrm{de,g} g}$ & $5^{\mathrm{e}, \mathrm{fg}}$ & $22 \mathrm{f}$ & $27^{\mathrm{g}}$ & 21 \\
\hline \multicolumn{8}{|l|}{ Receive the most effective drugs } \\
\hline Very confident & $36^{c, d, e, f}$ & $32^{c, d, e, f}$ & $23^{\mathrm{d}, \mathrm{g}}$ & $45^{\mathrm{e}, \mathrm{fg}}$ & $20^{\mathrm{fgg}}$ & $25^{\mathrm{g}}$ & 33 \\
\hline Somewhat confident & 47 & $50^{\mathrm{d}, \mathrm{f}, \mathrm{g}}$ & $49^{\mathrm{g}}$ & 45 & $50^{\mathrm{fg}}$ & 45 & 44 \\
\hline Not very/not at all confident & $15^{c, \mathrm{~d}, \mathrm{f}, \mathrm{fg}}$ & $16^{\text {c,de, f,g }}$ & $26^{\mathrm{d}, \mathrm{g}}$ & $9^{\text {ef,gg }}$ & $27^{\mathrm{g}}$ & $26^{\mathrm{g}}$ & 21 \\
\hline \multicolumn{8}{|l|}{ Receive the best medical technology } \\
\hline Very confident & $39^{\mathrm{b}, \mathrm{c}, \mathrm{de}, \mathrm{f}}$ & $28^{\mathrm{cd}, \mathrm{g} g}$ & $24^{\mathrm{d}, \mathrm{g}}$ & $46^{\mathrm{e}, \mathrm{fg}}$ & $25^{\mathrm{g}}$ & $27^{\mathrm{g}}$ & 38 \\
\hline Somewhat confident & $45^{\mathrm{b}, \mathrm{e}}$ & $53^{\mathrm{c}, \mathrm{d}, \mathrm{f}, \mathrm{g}}$ & $46^{\mathrm{e}}$ & 47 & $52^{\mathrm{fg}}$ & 46 & 43 \\
\hline Not very/not at all confident & $15^{\text {cd, }, \text { e,f }}$ & $18^{\text {c,d,eff }}$ & $27^{\mathrm{d}, \mathrm{e}, \mathrm{fg}}$ & $5^{\mathrm{e}, \mathrm{fg} g}$ & 21 & $23^{\mathrm{g}}$ & 18 \\
\hline Elective surgery in past 2 years & $16^{\mathrm{b}, \mathrm{f}}$ & $11^{\mathrm{fgg}}$ & $13^{\mathrm{fg}}$ & $13^{\mathrm{f}}$ & $14^{\mathrm{f}}$ & $8^{\mathrm{g}}$ & 16 \\
\hline \multicolumn{8}{|l|}{ Wait for surgery } \\
\hline$<1$ month & $59^{\mathrm{b}, \mathrm{c}}$ & $32^{\text {c,de,g }}$ & $72^{\mathrm{d}, e, \mathrm{fg} g}$ & $47^{\mathrm{g}}$ & $55 f$ & $40^{\mathrm{g}}$ & 62 \\
\hline$>6$ months & $9^{c, g}$ & $14^{\text {c,de,g }}$ & $3^{\mathrm{f}}$ & $2^{\mathrm{f}}$ & $4 f$ & $15^{\mathrm{g}}$ & 4 \\
\hline \multicolumn{8}{|l|}{ Access problems because of cost during past year } \\
\hline Did not visit doctor when sick & $13^{\mathrm{b}, \mathrm{de}, \mathrm{f}, \mathrm{g}}$ & $4^{\text {c,de, f,g }}$ & $12^{\mathrm{d}, \mathrm{efg} g}$ & $1^{\mathrm{e}, \mathrm{g}}$ & $19^{\mathrm{fg}}$ & $2^{\mathrm{g}}$ & 25 \\
\hline $\begin{array}{l}\text { Skipped medical test, treatment, or follow-up } \\
\text { recommended by doctor }\end{array}$ & $17^{\mathrm{b}, \mathrm{b}, \mathrm{d}, \mathrm{effg}}$ & $5^{\text {c,d,ef,fg }}$ & $8^{\text {de,f,fg }}$ & $2^{\mathrm{e}, \mathrm{g}}$ & $13^{\mathrm{fg}}$ & $3^{\mathrm{g}}$ & 23 \\
\hline Did not fill Rx or skipped doses & $13^{\mathrm{b}, \mathrm{d}, \mathrm{gg}}$ & $8^{\mathrm{c}, \mathrm{f}, \mathrm{fg}}$ & $11^{\mathrm{d}, \mathrm{d}, \mathrm{g}}$ & $2^{\mathrm{e}, \mathrm{fg}}$ & $10^{\mathrm{fg}}$ & $5^{g}$ & 23 \\
\hline Yes to at least one of the above & $26^{\mathrm{b}, \mathrm{d}, \mathrm{f}, \mathrm{g} g}$ & $12^{\text {c,def, }, \mathrm{g}}$ & $21^{\mathrm{d}, \mathrm{fg}}$ & $5^{\mathrm{e}, \mathrm{fg}}$ & $25^{\mathrm{fg} g}$ & $8^{\mathrm{g}}$ & 37 \\
\hline \multicolumn{8}{|c|}{ Out-of-pocket expenses for medical bills in the past year, in U.S. \$ equivalent } \\
\hline None & $13^{\mathrm{b}, \mathrm{c}, \mathrm{d} f \mathrm{f}}$ & $21^{\text {c,de, f, }, \mathrm{g}}$ & $9^{\mathrm{d}, \mathrm{f}}$ & $38^{\mathrm{e}, \mathrm{fg}}$ & $12^{\mathrm{f}}$ & $52^{\mathrm{g}}$ & 10 \\
\hline$\$ 1-\$ 100$ & $11^{\mathrm{b}, \mathrm{c}, \mathrm{d}, \mathrm{e}}$ & $17^{\mathrm{f}, \mathrm{g}}$ & $17^{\mathrm{f} g \mathrm{~g}}$ & $15^{\mathrm{g}}$ & $17^{\mathrm{fg}}$ & 12 & 9 \\
\hline More than $\$ 1,000$ & $19^{\mathrm{b}, \mathrm{c}, \mathrm{d}, \mathrm{e}, \mathrm{fg}}$ & $12^{\mathrm{d}, \mathrm{fg}}$ & $10^{\mathrm{d}, \mathrm{f} g \mathrm{~g}}$ & $5^{e, g}$ & $10^{\mathrm{fg}}$ & $4^{\mathrm{g}}$ & 30 \\
\hline $\begin{array}{l}\text { Had serious problems paying/unable to pay } \\
\text { medical bills in the past year }\end{array}$ & $8^{\mathrm{b}, \mathrm{b}, \mathrm{d}, \mathrm{fg} \mathrm{g}}$ & $4^{e, f, g}$ & $4^{e, f, g}$ & $5^{\mathrm{e}, \mathrm{fg} g}$ & $8^{f, g}$ & $1^{\mathrm{g}}$ & 19 \\
\hline
\end{tabular}

SOURCE: Commonwealth Fund International Health Policy Survey, 2007.

NOTES: Reading from left to right starting with Australia, the letter indicates significant differences with countries to the right

$(p<0.05)$, as indicated.

$b$ Different from Canada.

c Different from Germany.

d Different from the Netherlands.

e Different from New Zealand.

f Different from U.K.

$g$ Different from U.S.

Adapted from Ref. 25 
Australia, New Zealand, and Germany were midway between the extremes with Canada ranking low with cost related concerns.

Twenty percent of US and German adults perceived that there was significant waste in medical care and insurance billing, while adults in the Netherlands, along with adults from the United States, felt that they had to spend time on paperwork or disputes.
Among the 3 countries where adults can switch their basic insurance coverage, the United States, Germany, and Netherlands, frequent changes were highest in the United States with $32 \%, 25 \%$ in the Netherlands, and the Germans with a $10 \%$ rate of switching.

Table 4 illustrates health spending in OECD countries. However, there are also contradictory views of health care in various countries.

Table 4. Health spending in Organisation for Economic Cooperation and Development (OECD) countries, 2004.

\begin{tabular}{|c|c|c|c|c|c|c|c|}
\hline \multirow[b]{2}{*}{ Country } & \multicolumn{2}{|c|}{ Health spending per capita } & \multirow[b]{2}{*}{$\begin{array}{r}\text { Total health } \\
\text { spending } \\
(\% \text { GDP })\end{array}$} & \multicolumn{4}{|c|}{ Spending per capita, by component (U.S. \$PPP) } \\
\hline & \begin{tabular}{|r|} 
Total health \\
spending (US \\
$\$ P P P)$ \\
\end{tabular} & $\begin{array}{r}\text { Average real } \\
\text { annual growth, } \\
1994-2004(\%) \\
\end{array}$ & & Inpatient & Outpatient & $\begin{array}{r}\text { Prevention, } \\
\text { public health }\end{array}$ & $\begin{array}{r}\text { Other misc. } \\
\text { services }\end{array}$ \\
\hline Australia & 3,120 & 4.4 & 9.6 & 1,198 & 950 & 46 & 926 \\
\hline Austria & 3,124 & 4.2 & 9.6 & 1,302 & 727 & 63 & 1,032 \\
\hline Belgium & $3,044^{\mathrm{a}}$ & $4.1^{\mathrm{b}}$ & $10.1^{\mathrm{a}}$ & $-c$ & $-c$ & $40^{\mathrm{a}}$ & $3,004^{a}$ \\
\hline Canada & 3,165 & 2.8 & 9.9 & 914 & 792 & 185 & 1,274 \\
\hline Czech Rep. & 1,361 & 3.3 & 7.3 & $427^{d}$ & $336^{d}$ & 27 & $-\mathrm{e}$ \\
\hline Denmark & 2,881 & 2.3 & 8.9 & 868 & 734 & 15 & 1,264 \\
\hline Finland & 2,235 & 3.1 & 7.5 & 777 & 770 & 87 & 601 \\
\hline France & 3,159 & 3.2 & 10.5 & 1,069 & 670 & 90 & 1,330 \\
\hline Germany & 3,043 & 2.1 & 10.6 & 1,061 & 700 & 100 & 1,182 \\
\hline Greece & 2,162 & 3.6 & 10.0 & $-\mathrm{c}$ & $-\mathrm{c}$ & $-\mathrm{c}$ & $-\mathrm{c}$ \\
\hline Hungary & 1,276 & 3.8 & 8.0 & $323^{d}$ & $252^{\mathrm{d}}$ & $54^{\mathrm{d}}$ & $-\mathrm{e}$ \\
\hline Iceland & 3,331 & 4.9 & 10.2 & 1,804 & 767 & 40 & 700 \\
\hline Ireland & 2,596 & 6.9 & 7.1 & $-\mathrm{c}$ & $-c$ & $-\mathrm{c}$ & $-c$ \\
\hline Italy & 2,467 & 3.0 & 8.7 & 1,088 & 719 & 15 & 645 \\
\hline Japan & $2,249^{\mathrm{a}}$ & $2.3 \mathrm{~b}$ & $8.0^{\mathrm{a}}$ & $879^{a}$ & $704^{\mathrm{a}}$ & $50^{\mathrm{a}}$ & $616^{a}$ \\
\hline Korea & 1,149 & 6.8 & 5.6 & 264 & 421 & 21 & 443 \\
\hline Luxembourg & 5,089 & 7.7 & 8.0 & 1,686 & 1,281 & 63 & 2,059 \\
\hline Mexico & 662 & 2.1 & 6.5 & 225 & 198 & 18 & 221 \\
\hline Netherlands & 3,041 & 3.3 & 9.2 & $1,043^{\mathrm{d}}$ & $604^{\mathrm{d}}$ & 148 & -e \\
\hline New Zealand & 2,083 & 3.8 & 8.4 & $-\mathrm{c}$ & $-\mathrm{c}$ & $-\mathrm{c}$ & $-\mathrm{c}$ \\
\hline Norway & 3,966 & 4.6 & 9.7 & 1,623 & 721 & 75 & 1,547 \\
\hline Poland & 805 & 6.1 & 6.5 & 226 & 165 & 14 & 400 \\
\hline Portugal & 1,824 & 5.2 & 10.1 & 410 & 562 & 36 & 816 \\
\hline Slovak Rep. & $777^{\mathrm{a}}$ & $-c$ & $5.9^{\mathrm{a}}$ & $236^{\mathrm{a}}$ & $119^{\mathrm{a}}$ & $13^{\mathrm{a}}$ & $409^{a}$ \\
\hline Spain & 2,094 & 3.8 & 8.1 & 543 & 697 & 29 & 825 \\
\hline Sweden & 2,825 & 3.8 & 9.1 & 885 & 1,381 & $-c$ & 559 \\
\hline Switzerland & 4,077 & 2.9 & 11.6 & 1,941 & 1,116 & 89 & 931 \\
\hline Turkey & 580 & 10.4 & 7.7 & $-c$ & $-c$ & $-\mathrm{c}$ & $-c$ \\
\hline U.K. & 2,508 & 4.1 & 8.1 & $-\mathrm{c}$ & $-\mathrm{c}$ & $-\mathrm{c}$ & $-\mathrm{c}$ \\
\hline U.S. & 6,102 & 3.7 & 15.3 & 1,636 & 2,668 & 224 & 1,574 \\
\hline OECD median & 2,552 & 3.8 & 8.8 & 900 & 712 & 48 & 876 \\
\hline
\end{tabular}

SOURCE: Organization for Economic Cooperation and Development, OECD Health Data 2006 (Paris: OECD, 2006).

NOTES: Average real annual growth calculated by authors using national currency units at 2000 gross domestic product (GDP) price level. Average annual growth rates are calculated using national currency units. Outpatient services spending includes physician, dental, and ancillary services. Inpatient services spending includes long-term nursing care and curative and rehabilitative care. "Other misc. services" includes personal health care, day care, home care, pharmaceuticals and other medical nondurables, therapeutic and other medical nondurables, and health administration and insurance. PPP is purchasing power parity.

a 2003.

b 1994-2003.

c Data not available for 2002, 2003, or 2004.

$d 2002$.

e Data cannot be calculated given mismatch in years of data. 


\section{France}

The French health care system was rated the best in the world in 2001, not because of its economic sustainability, but because of its universal coverage, responsive health care providers, patient and provider freedoms, and the health and relative longevity of the country's population (20). However, there are less than apparent contradictions to these statistics. The World Health Organization (WHO), which obtained the health-related information from respective ministries of health, does not independently verify the provided statistics. It appears the same is the case with the Commonwealth Fund (25). Therefore, which such statistics may superficially depict a positive health care environment, as the fiscal infrastructure of the French medical system is less than "healthy."

In 2004, a government commission has warned that without fundamental reforms, France's National Health Service, rated the best in the world by the WHO, will collapse within the next 15 years (22). The commission also forecasted that in 2004, the French government will be $€ 11$ billion in the red - will be a staggering $€ 70$ billion over-budget by 2020 .

While most French patients think their health service is outstanding, with a first-class level of care for minimal personal outlay, the system is, however, very expensive. Further, patients are free to go as often as they like to as many of the country's 94,000 GPs or 89,000 specialists, ask for whatever treatment or medicines they like, and expect to get most of the cost reimbursed by the state. However, France's health care budget is the world's third largest, accounting for $9.8 \%$ of the GNP compared with $10.4 \%$ in Germany and $6.9 \%$ in Britain. Further, it has been stated that the system is unnecessarily complex and wasteful, rewarding doctors who see patients as often as possible, and encouraging them to over-prescribe (22). In fact, Henley (22) described that the French are now Europe's heaviest pill poppers, consuming more than three times as many as their neighbors in Britain, Germany, and Italy.

Dutton (20) provides a critical view of France's model health care system. While the French system is dissimilar to the United States and less expensive, it appears that the French also share distaste for restrictions on patient choice and they insist on autonomous private practitioners rather than a British-style national health service, which is described as "socialized medicine." However, virtually all physicians in France participate in the nation's public health insurance. In addition, practice liability is greatly diminished by a tort-averse legal system, and medical schools, although extremely competitive to enter, are tuition-free. Further, France's doctors do not face the high nonmedical personnel payroll expenses that burden American physicians due to a standardized and speedy system for physician billing and patient reimbursement used in electronic funds. In contrast to the United States where overhead may run as high as $50 \%$ of gross revenues, French medical offices are without nonmedical personnel and in contrast to Canada and Britain, there are no waiting lists for elective procedures and patients need not seek pre-authorizations.

In contrast to all the advantages of the French health care system, its status of being on the verge of collapse (22), the deficiencies of the French health care system are illustrated by the inability to handle a simple heat emergency (31-34). At least 35,000 people died as a result of the record heat wave the scorched Europe in August 2003 (33). The searing August heat claimed about 7,000 lives in Germany, nearly 4,200 lives in both Spain and Italy, over 2,000 deaths in the United Kingdom, and almost 15,000 deaths in France. The bulk of the victims, specifically in France - many of them elderly, died during the height of the heat wave, during a season when many of the doctors are on vacation. However, the National General Practitioners Union stated that only about $20 \%$ of general practitioners were away during the heat wave.

\section{Germany}

German health care, hailed as one of the best by the United States, is criticized in Germany with expenditures for health care representing $10.8 \%$ of the GDP - higher than the average of $8.9 \%$ among the 30 countries in the Organisation for Economic Co-operation and Development, even though less than the United States. In Germany, ambulatory health care is provided by general practitioners and specialists and inpatient care is delivered by a mix of public, non-profit, and private providers. University clinics in Germany are managed by the federal states (35). It is touted that the public enjoys equal and easy access to care, and waiting lists and explicit rationing of health care have not been known in Germany. However, during the past 3 to 4 decades, the German medical regulation has permitted health insurance companies to control many aspects of medical practice. Consequently, the German concept of good and affordable medicine has changed by placing ever-greater limits on doc- 
tors' latitude in making medical decisions for their patients. Further, similar to the United States, medicine has been increasingly subjected to economic considerations with increases in the cost of diagnostic and therapeutic procedures, coinciding with the shrinking of the tax base (36).

Physicians on strike, a phenomenon that is unthinkable in the modern world, is happening - although, not yet in the United States. However, striking is not impossible for German physicians $(35,37)$. Over 100,000 German physicians took part in strikes to protest the government health policies with strikes lasting 1 day to 90 days, with doctors gaining concessions.

Between 1991 and 2004, 1 in every 10 German hospitals was closed, resulting in a $20 \%$ reduction in the number of hospital beds, with simultaneous reduction of hospital stays by $38 \%$, but increasing the number of patients treated by $20 \%$. In a 2003 survey, it was shown that physicians in German hospitals spent more than one-third of their working time on documentation and other administrative duties. Traditionally, the German hospital system has made little use of advanced-practice nurses to perform routine medical tasks and coding assistants to perform nonmedical tasks. This is in contrast to the United States where there is a movement claiming that increasing mid-level providers will reduce health care costs and improve access.

The similarities between US and German physicians are that in both countries, they have been facing budget cuts throughout the past decade and continue to face them into the future. Unfortunately, in the United States, practice expenses continue to climb with declining reimbursements.

\section{Netherlands}

Twenty-five years ago, the health care system of the Netherlands was operating under top-down costcontainment policies, such as regulation of doctors' fees and hospital budgets, that were widely criticized for lacking incentives for efficacy and innovation (38). In 1986, the Dekker Committee, an independent group appointed by the Dutch government to seek a solution, recommended market-oriented reform within the context of the national health insurance system. With preparations spanning over the next 20 years, the Dutch government enacted the Health Insurance Act (HIA), on January 1, 2006, under which every person who legally lives or works in the Netherlands is obliged to buy, from a private insurance company, in- dividual health insurance whose benefits are specified by law (Table 5). Since non-enrollment is associated with penalties, by the end of 2007 , about $98.5 \%$ of eligible Dutch people have enrolled in health insurance programs. In this system, benefits are strictly defined by the government with voluntary deductibles, and insurers are allowed to sell various types of supplemental insurance.

A prospective payment systems exist, but insurers and hospitals are allowed to negotiate prices freely and to contract selectively. However, these benefits do not come without a cost. All individuals must pay an income-related contribution, $6.5 \%$ of the first $€ 30,000$ in annual income to the Risk Equalization Fund. Further, employers are obliged to compensate their employees for these contributions, but this is then taxable income for the employees. Apart from this, all adults must pay a community-rated premium which means the same price for the same benefits, regard-

Table 5. Key elements of the Dutch health care system.

Mandatory basic health insurance for everyone, purchased through private insurance companies

Annual consumer choice of insurer and insurance products

Open enrollment and community rating

Premium subsidies for elderly people and those at high risk of disease,

through a risk-equalization system

Voluntary deductible up to $€ 500$ per person per year

Insurers allowed to sell other types of insurance (e.g., supplementary insurance)

Insurers intended to be the prudent buyers of care on behalf of their members

General practitioners to serve as gatekeepers

Insurers permitted to contract selectively with doctors and hospitals

Health maintenance organizations and preferred provider arrangements allowed

In transition toward managed competition

Adapted from ref. 38 
less of their own level of health to the insurer of their choice (insurers set their own price).

Risk equalization is an essential part of this system. The expenses are estimated on the basis of predictive modeling. The Risk Equalization Fund reimburses the insurers appropriately based on the care, more or less, thus, partially removing any incentives for risk selection.

In the Netherlands, insurers are similar to American health maintenance organizations, theoretically, the customer-driven organizations of care. Similar to managed care in the United States, insurers establish many techniques, including protocols, provider selective, incentive contracting, and standardized approaches to disease management.

While the Dutch system is still a work in progress, riddled with numerous problems, it is surprising to know that it was actually first designed and proposed for the United States (39). Further, such proposals are still alive in the United States and some presidential candidates are proposing such systems (40).

\section{Britain}

While the United States is looking for modernization or universal health care coverage, Britain's national health system, the most well known, is going through a troubled transformation (41). The creation of Britain's National Health Care Service (NHS) in 1948 provided political friction and medical opposition - similar to the creation of Medicare in the United States. While NHS went through turbulent phases, in 2006 it reached a crisis. The NHS trade union staged protests as staff were laid off, patients worried as media stories about hospitals delaying treatment or economizing on drugs multiplied, the Chief Executive of the NHS took early retirement, and the Prime Minister rushed to the defense of the government's policies (41). The NHS fiscal troubles started at the beginning of 2000 leading to a pledge of large increases in funding for the NHS that were designed to bring health care spending up to the level of that in other Western European countries. In fiscal year 1999, spending on the NHS was in US dollars approximately $\$ 75$ billion, which by fiscal year 2005 increased to $\$ 132$ billion with a planned increase to almost $\$ 160$ billion by 2007 (42). Despite the efforts of the labor government in the first 5 years from 1997 to 2002, costs are rising (43). Due to its infrastructure, NHS as a tax-funded service, is always more centralized than other health care systems; however, such centralization also hindered modernization with poor performance. The modifications included increasing the capacity of the NHS, decentralizing by transmitting the power to the periphery increasing the role of the primary care trusts with over 300 organizational bodies, hands off control, providing patient choice, and driving the new system to "payment by results."

\section{Canada}

The Canadian health care systems has been lauded and criticized $(44,45)$ while sometimes viewed as an idealized system of universal access to care. The fuzzy economics of Canada's health care infrastructure has been criticized for leading to poor management of health care delivery in a geographically broad distributional system. The increased awareness of rationing of care, lack of innovation, and delays in accessing health care services caused by the Canadian system have lead to growing public and physician interest in developing other, more market-based options. Such a turn toward a market-model mentality may lead to local governments seeking some form of privatization in an attempt to mend economic woes, shrink long waiting lists for care, and provide better distributional equity of services.

\section{Health Care Coverage in the US}

Health care coverage in the United States is provided by private health insurance (mainly through sponsorship of employment-based coverage), Medicare for the elderly and disabled, and Medicaid for the poor, disabled, and low income elderly (7,9,46-48). In addition, health insurance coverage is also provided by federal, state, and other programs.

A reversal phenomenon is being observed in the United States. Employment-based coverage excluding the elderly with retiree coverage, peaked in 2000 at 164.4 million $-62 \%$ of the non-elderly population - and then fell by almost 5 million in the subsequent 4 years (47). Individual purchasing of health benefits declined during the 1990s, even though it has increased slightly by 1 million since 2001. In 2004, with the population of the United States at 291.2 million, employment based coverage was provided to 174.2 million persons, of which 159.5 million were non-elderly, and 27 million persons purchased individual insurance, of which 17.4 million were non-elderly. Even then, the commercial insurance industry had great financial success through 2006. Rather tragic for the US health care system is the weakening of employer commitment to 


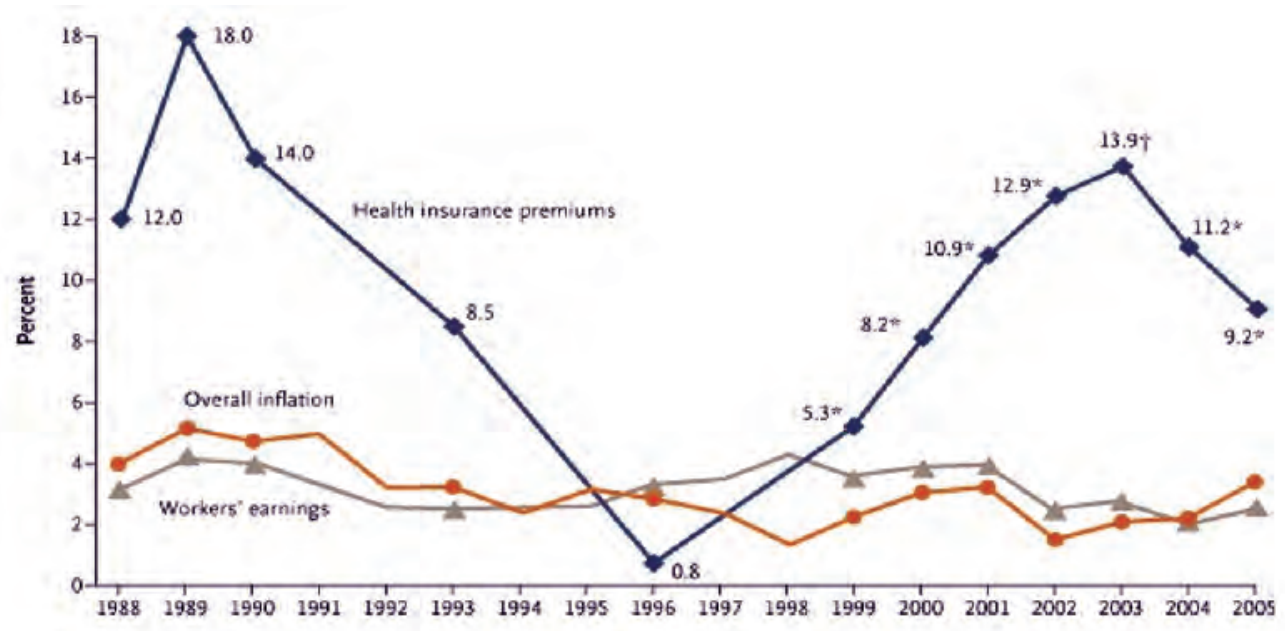

Data on increases in health insurance premiums reflect the cost of premiums for a family of four. Asterisks indicate an estimated percentage that differs significantly $(P<0.05)$ from that for the previous year. The dagger indicates an estimated percentage that differs significantly from that for the previous year $(P<0.01)$.

Fig. 11. Increases in health insurance premiums, as compared with overall inflation rates and workers' earnings, 1988 - 2005. Adapted from ref. 50

providing coverage and strengthening interest by public programs to offer coverage through private plans $(49,50)$. Consequently, Medicare and Medicaid are becoming the world's largest insurance programs.

The growing cost of insurance premiums which have been rising at the multiple of general inflation has captured the attention of US employers (50-53). Figure 11 illustrates increases in health insurance premiums, as compared with overall inflation rates and workers earnings from 1988 to 2005, with yearly increases of health insurance premiums as high as $18 \%$ (54). The slogan of Clinton's campaign was that the US automobile industry spends more per car on health care than on steel, paraphrasing Lee lacocca, the retired chairman of the Chrysler Corporation, who advocated for national health insurance (55).

Public-sector spending on health care increased to $\$ 902.7$ billion in 2005 . Figure 12 illustrates contributions to health care spending of approximately $\$ 2$ trillion in 2005 , of which the majority was from households followed by private business, federal government, state and local governments. However, the government's role in financing health care is showing a striking growth. It is predicted that by 2016, the government will be paying $48.7 \%$ of the nation's health care bill up from 38\% in 1970 and 40\% in 1990.

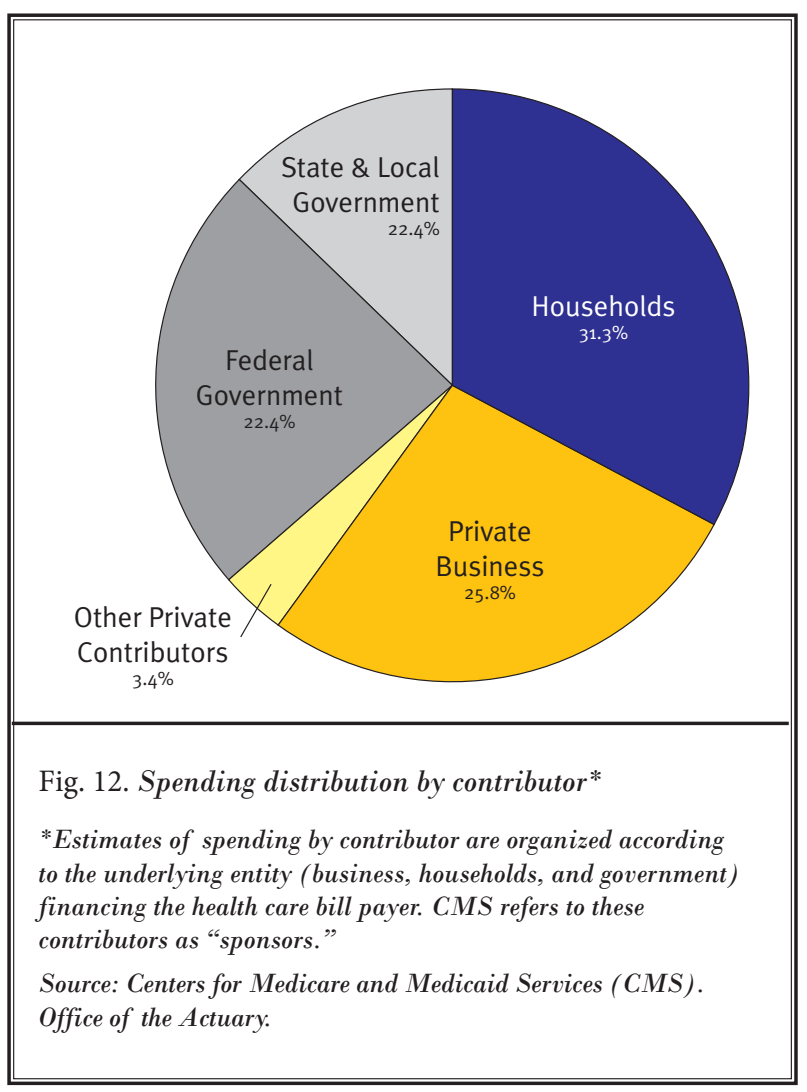




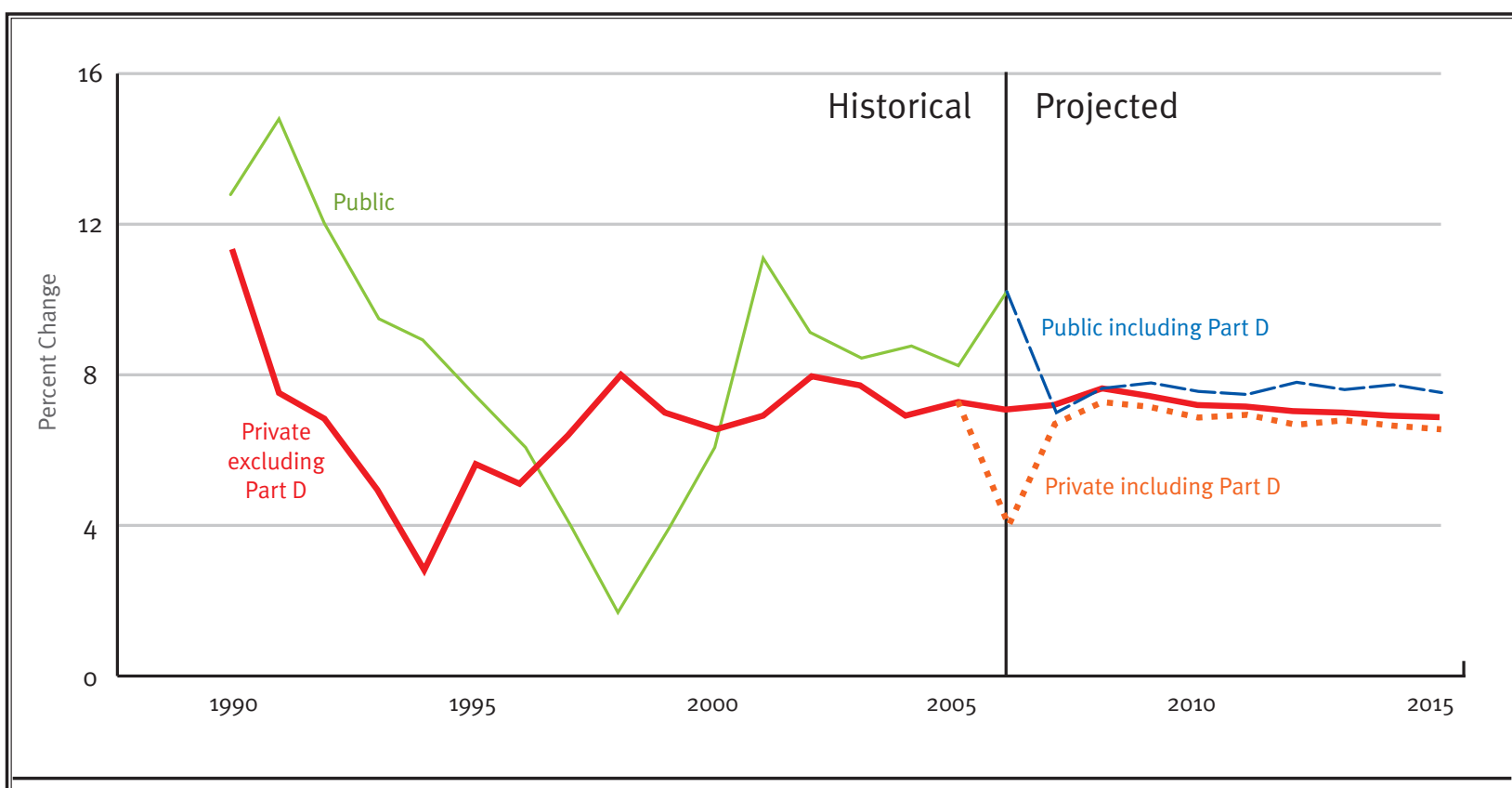

Fig. 13. Private and public personal health care spending, excluding and including the impact of Medicare Part D, 1990-2016.

Adapted from Ref. 7.

Figure 13 shows private and public personal health care spending, excluding and including the impact of Medicare Part D (7).

Escalating health care costs have prompted concerns about the financial solvency of Medicare. With the generation of baby boomers poised to enter retirement age and a general "graying" of the US population, the trends in health care spending offer a grim picture of the future of the US health care system's viability.

Medicaid spending also is skyrocketing $(7,46,49)$. Combined state and federal Medicaid spending was projected to be $\$ 313.5$ billion in $2006(7,49)$. Composition of the Federal Budget in 2006 showed Medicare, Medicaid and State Children's Health Insurance Program (SCHIP) accounting for $19 \%$ of the federal expenditures, whereas Social Security accounted for $21 \%$ of the Federal Budget (Fig. 14). However, even with Iraq and Afghanistan, federal spending is below average at the present time for recent decades (Fig. 15). Based on Congressional Budget Office data, it has been calculated that to balance the budget by 2012, while extending the tax cuts and continuing alternative minimum tax relief, policy makers would have

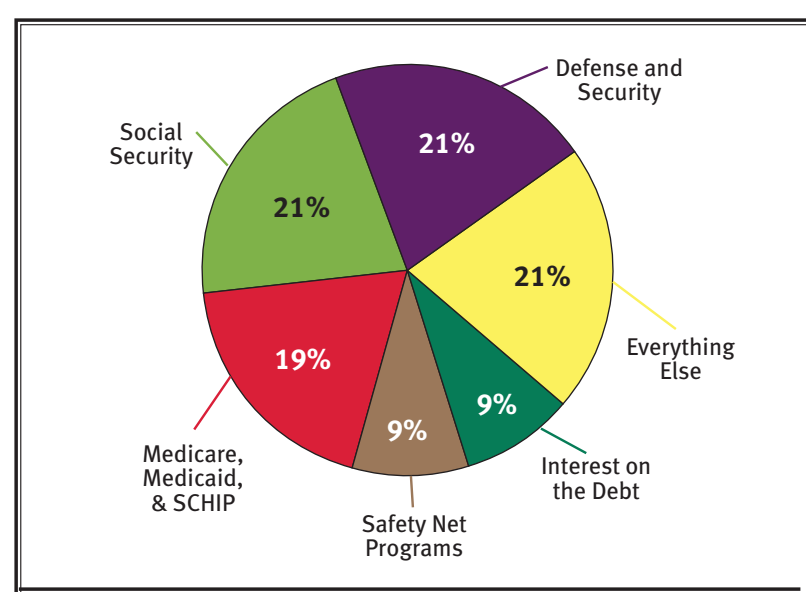

Fig. 14. Composition of Federal budget in 2006. Source: Office of Management and Budget data.

to cut social security benefits by $32 \%$ or cut defense spending by $42 \%$ or cut Medicare by $51 \%$ or cut every other program except Social Security, Medicare, and defense by $20 \%$.

In the past decade, the cost of monthly premiums paid by all Medicare enrollees has more than doubled (from \$43 to \$96) and is expected to keep climbing. 


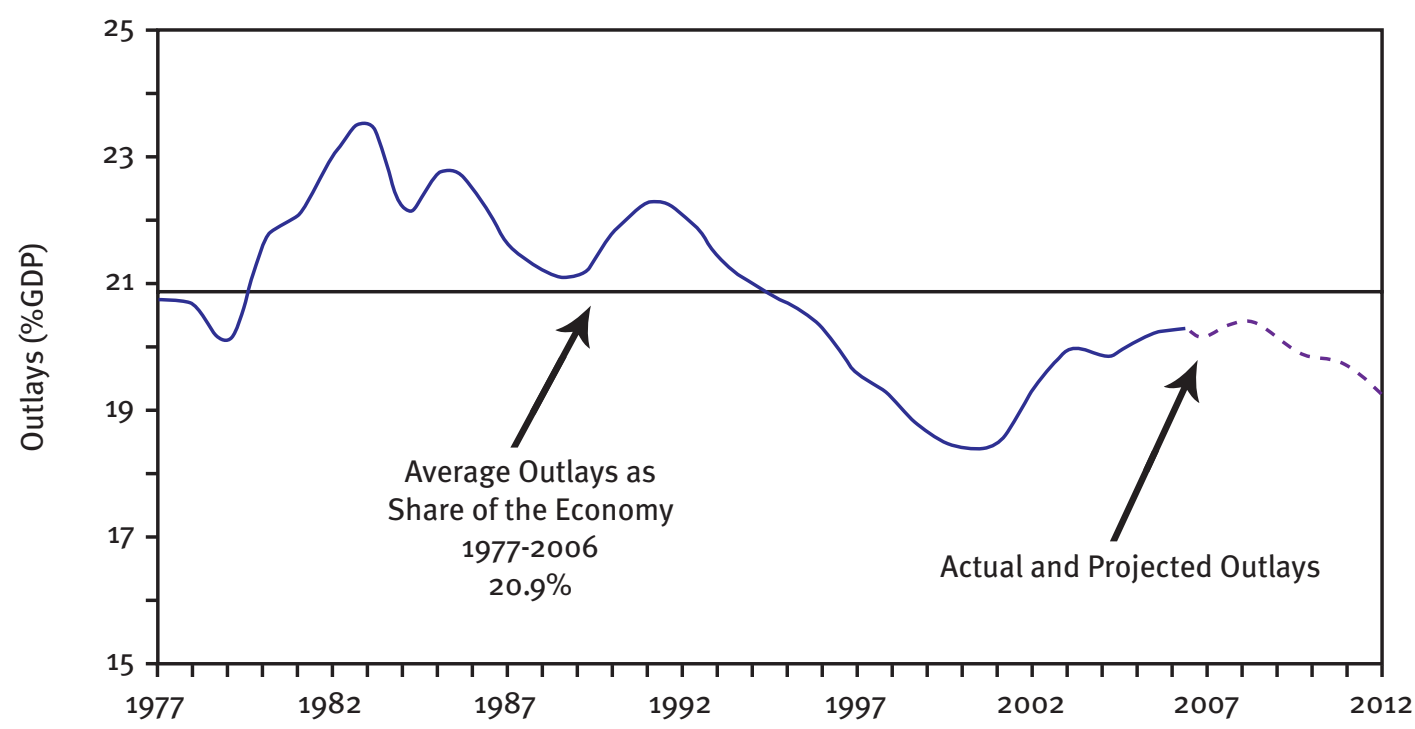

Fig. 15. Even with Iraq and Afghanistan, federal spending is below average for recent decades.

Source: CBPP calculations based on Congressional Budget Office data.

\section{Public Perceptions in the US}

Presidential politics have provided a resurgence of interest in health care reform in recent months (56). Comprehensive health care reform essentially disappeared from the national agenda after the Clinton administration failed to enact universal coverage in 1993 and 1994. Instead, Congress adopted incremental measures that enjoyed bipartisan support. Oberlander (56) observed that the retreat from comprehensive reform reflected, in part, the calculus that ambitious plans were too controversial and too hazardous to their sponsors' political health to attempt. However, after 2 terms of Bill Clinton and the near completion of 2 terms of George W. Bush, once again, health care ranks as the top domestic issue in opinion polls, and there is talk of major reform by most presidential candidates as the 2008 election approaches.

The current change in the atmosphere and proposals of bold comprehensive plans once again illustrates the changing political calculus. The surveys of the American public's health priorities in 2006 showed that health care is an important, but a second-tier issue in terms of priorities for government action (57).
However, American's top health care concerns are mostly related to economic insecurity, namely the rising costs and the problems of the uninsured. While most Americans think that the health system is not in crisis, the public remains dissatisfied. Thus, assumptions of political landscape have been made of changing, creating a climate that is supportive of increased health spending and substantial policy changes. However, as illustrated in Figure 16, changing public attitudes toward the US health care system from 1982 to 2007 do not reflect these feelings (58). The ratings of "fundamental changes needed," and the "system need to be completely rebuilt," have decreased from the 1990s to the 2000s while the ratings of "only minor changes are needed" have increased. Figure 17 illustrates the opinion of the US public based on total population and political party affiliation $(56,59)$.

As illustrated in Figure 18, a majority of Americans would like to see a new health plan that would make a major effort to provide insurance for all or nearly all of the uninsured and would involve a substantial increase in spending (60). 


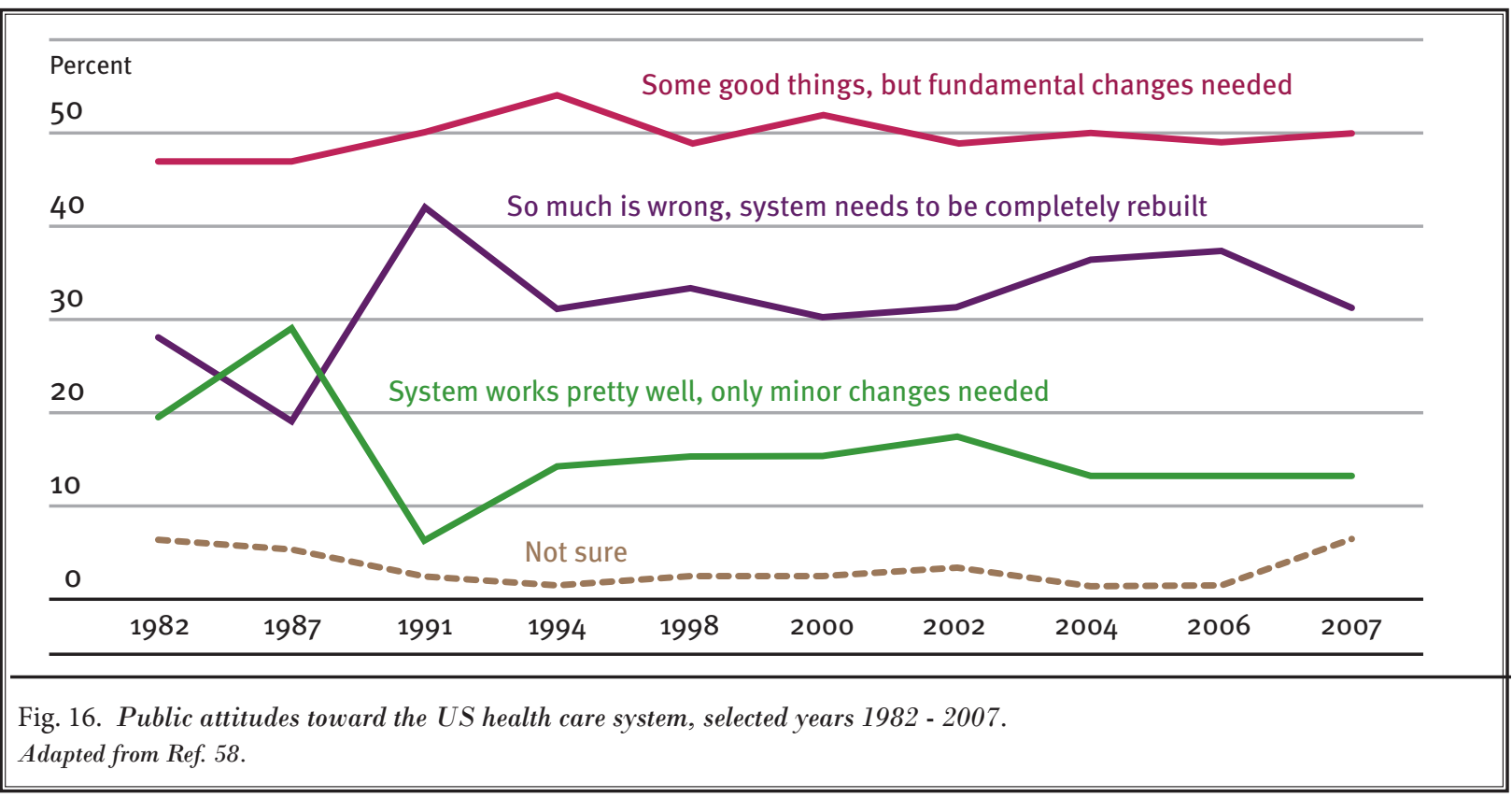

A new health plan that would make a major efford to provide insurance for all or nearly all of the uninsured and would involve a substantial increase in spending
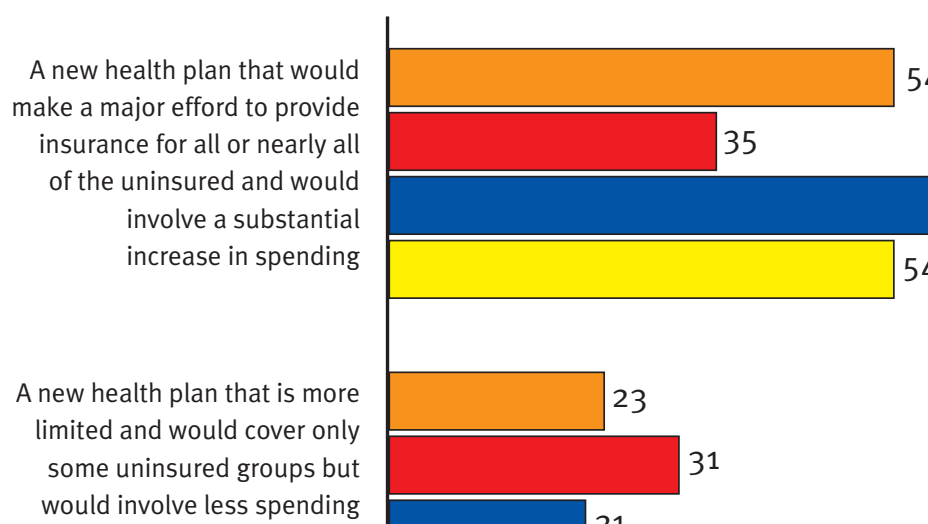

54

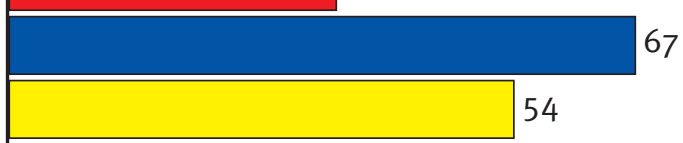

A heath plan that would kep

A health plan that would keep things basically as they are

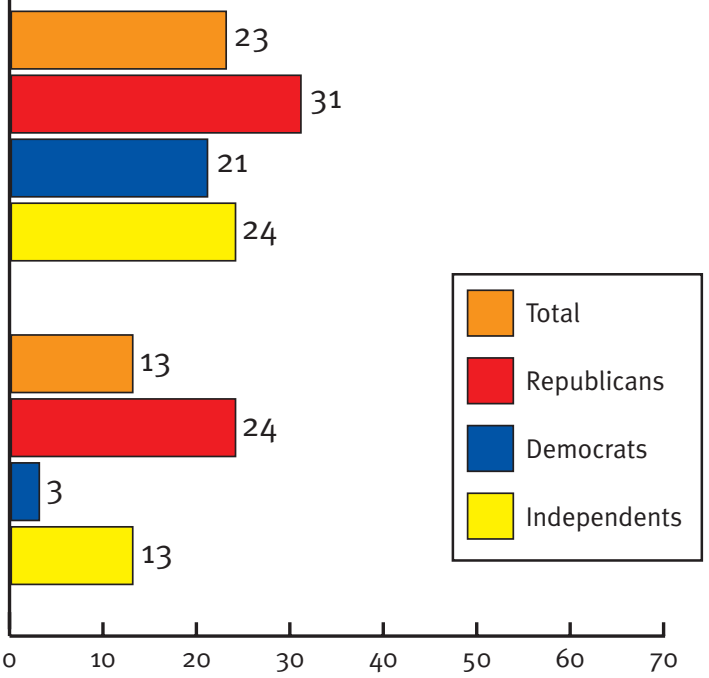

Percent of Respondents

Fig. 17. Illustration of opinion of the US public based on total population and political party affiliation. Adapted from Ref. 56. 


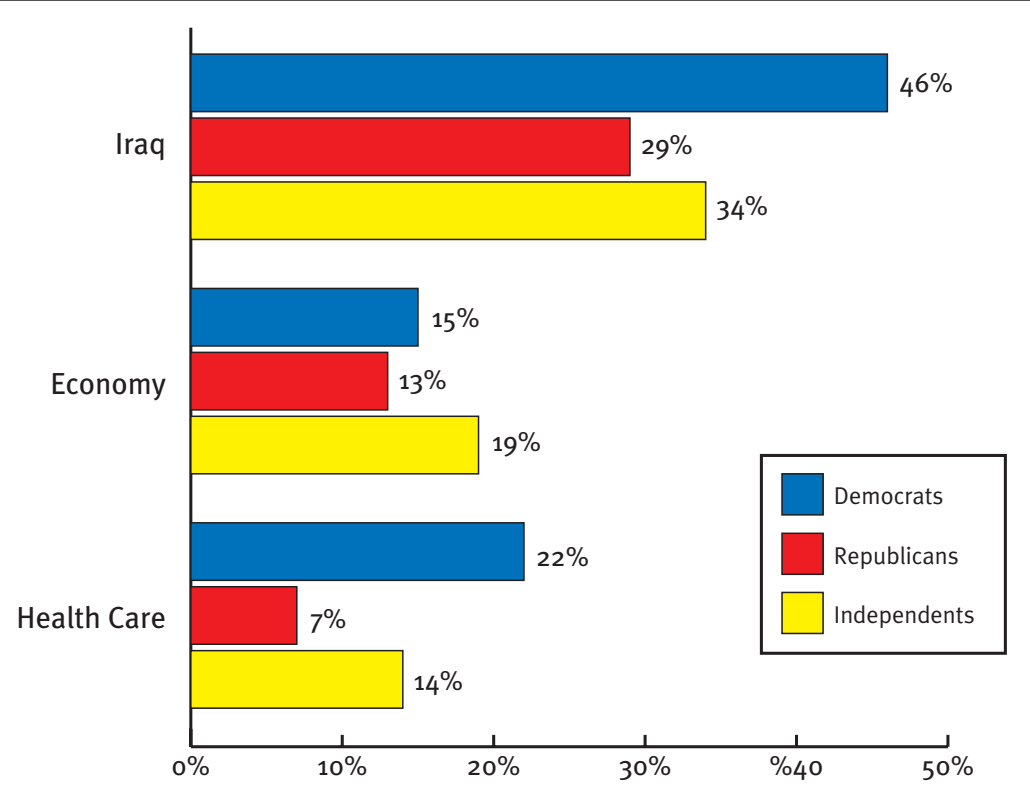

Fig. 18. Issues people say are top concerns in the presidential election.

Source: USA TODAY/Gallup Poll of 1,006 adults nationwide. Margins of error \pm 3 to 5 percentage points.

\section{Health Care for America: Radical Or Cosmetic Surgery}

Califano (1) has proposed re-conceiving the health care system from top to bottom with the elimination of public health enemy \#1; abuse and addiction involving all substances; by taking the profit out of poor health with the power of positive prevention and by rewarding individuals who take care of their health and by making good health accessible and fashionable to all; by a reality check for research and by bringing our resources more into line with the needs of this age and our civilization; by busting the medical monopolies including the training of mid level practitioners to provide primary care, liberalizing medical licensure boards, and disciplining problem doctors; and by freeing congressional contributions from the power of big insurers. While these solutions will still work, it will take great effort and courage not only on the part of the US government, but also by the public, physicians, hospitals, and insurers.

Hacker (3) provided a proposal for guaranteed, affordable health care for all Americans building on Medicare and employment-based insurance entitled "Health Care for America". This would extend insurance to all non-elderly Americans through a new Medicare-like program and workplace health insur- ance, while creating an effective framework for controlling medical costs and improving health outcomes to guarantee affordable, quality care to all. This program is considered to be comprehensive, realistic, consistent with American values and beliefs, and grounded in the best elements of the present system. It also combines employer and personal responsibility with a strong public commitment to ensuring that American workers and their families and American employers can afford coverage. Consequently, it promises better care, lower costs, more choice, healthier citizens, and immensely stronger guarantees for workers and their families with real savings for employers and state governments, and does so, in essence, provides a system without unraveling existing sources of health security, without forcing workers to obtain coverage on their own, and without pressuring patients into health savings accounts or tightly managed health maintenance organizations.

Health care for America has 3 central elements: 1) plans would be open to any legal US resident without good workplace coverage, 2) a requirement that employers and the self-employed would either purchase coverage comparable to Health Care for America for all their workers or pay a relatively modest payroll contribution ( $6 \%$ of payroll to fund Health Care for America coverage for all their employees), and 3) a re- 
quirement that Americans who remain without insurance take responsibility for their and their families by purchasing private coverage or buying into the Health Care for America plan. The benefits of this plan would be comprehensive.

In addition, out of pocket expenses will be fixed and, to encourage better health, preventive and wellchild care covered screenings would be provided to all beneficiaries at no out-of-pocket charge. In addition, a new independent benefits advisory commission would be created to determine what both the Health Care for America plan and Medicare should cover going forward, allowing for the harmonization of the 2 programs' benefits over time.

The advantages of this plan include building on the best aspects of workplace insurance while filling the gaps, using the Medicare model to contain costs and improve quality. However, the drawback is that Health Care for America would require new federal funding. However, it is proposed that savings could be achieved by various means including elimination of SCHIP and Medicaid, with spending lower than that of a universal Medicare plan. Further, the movement of workers for tax-favored private coverage into Health Care for America would reduce federal tax subsidies for employment-based insurance. Consequently, payroll and income tax receipts would rise due to the substitution of wages for health benefits among firms that pay less for insurance than they would have without reform. Finally, the remaining federal costs would be financed by various combinations of liquor and tobacco taxes and other dedicated levees and general revenues.

Another proposed framework to guide health care system reform (8) from McKinsey Global Institute provides 7 principles for health care reform. Of the 7 principles that health care intermediaries can use to affect supply and demand of health care goods and services, 2 relate to demand, 3 to supply, 1 to intermediation between supply and demand, and the final principle to the organization and operational framework necessary to allow the implementation of the first 6 . The 7 principles are as follows:

1) Prevent illness and injury by providing a healthpromoting infrastructure, reducing health-threatening environmental hazards by establishing comprehensive immunization programs and by promoting healthy lifestyles.

2) Promote value conscious consumption by providing information to support effective cost-benefit judgments, by fostering consumer choice, and by shaping supply for health care.

3) By promoting efficient capacity by assuring adequate physical resources, ensuring an adequate supply of labor, promoting the best use of medical technology and limiting interventions.

4) Ensuring quality among supplies by safeguards to raise the quality of health outcomes, by providing adequate service levels.

5) By promoting cost optimization among providers with optimizing costs in the acquisition and management of inputs. Optimizing cost and service delivery and by intermediation in health care.

6) Promoting sustainable finance mechanisms with sources of funds for financing health care, by providing payments to providers, and by instituting pay-for-performance impacting quality.

7) Strengthening intermediaries' capabilities by assisting to build organization capabilities, by building institutional skills, and by building accountability and awareness.

A different approach from the Research and Policy Committee of the Committee for Economic Development (61) proposed policies that bring about steady economic growth at high employment and reasonably stable prices, with quality, affordable health care for all, at the same time, moving beyond the employerbased health insurance system. The Committee for Economic Development (CED) does not support either a government-run command - and - controlled system, or a so-called consumer-directed system under which individuals take at least implicit responsibility for choosing their own therapies and treatments. Instead, the CED recommends market-based consumer choice among competing insurance and care-delivery plans that meet quality and coverage standards. A key recommendation is that this consumer choice must be responsible - that is the consumer, informed by mandatory and standardized reporting of quality and performance by insurers, must be able to save money by choosing a less-expensive plan. Another key recommendation is the establishment of an independent regulatory agency, fashioned after the Federal Reserve and the Securities and Exchange Commission, to report on the state of the health care sector in terms of inflation and affordability, and ensure the efficiency and fairness of the insurance market. The CED believes that such a reform of our health care financing systems would lead insurers and providers, through market competition, to fundamentally restructure the 
health care delivery system, improving both quality and affordability, achieving universal coverage and financial sustainability.

The CED believes that the program has the greatest prospect of achieving the 3 goals of restraining health care expenditures, achieving universal coverage, and improving quality. This program relies on incentives for individuals to choose both plans and providers that offer what those individuals judge to be the best combination of quality and price. This will also provide the strongest incentive to insurers and care providers to increase quality and restrain prices, creating a new dynamic toward improvement. At the same time, consumers who prefer today's model of care would be able to keep it, if they were willing to pay any difference in price. Further, the CED believes that merely extending coverage, even to universal coverage, under the current system, would not solve the core problem, due to cost of coverage growing faster than the economy's capacity to pay it, thus, coverage becoming an elusive phenomenon. However, there is no evidence that the system will work and provide universal coverage, curing all the ills of present day health care in the United States.

Some are proposing a US version of the Dutch model, which would provide an opportunity for US physician organizations to form their own health plans and present themselves directly to the consumer market, freeing them from control by large, remote, third-party insurance carriers and from the maddening complexity of having to deal with 15 to 30 different insurance companies and self-insured employers, each with its own payment criteria and plan designs (38). Further, medical groups could build their own consumer base and loyalties, designing their own coverage criteria, incentive schemes, utilization management, and other features. In reality, this system will not work in the United States, even though opinions appear to be favorable (62), due to numerous political conflicts among physician groups, physician specialties, family practitioners, and specialists, and overlapping care groups, each one fighting to preserve their own piece of the pie, the system's viability in the United States is difficult.

The American Medical Association (AMA) also proposed health insurance reform to expand insurance coverage through tax credits, consumer choice, and market enhancements (63). Under this proposal, individually owned insurance would enable people to maintain coverage without disruption to existing pa- tient-physician relationships, regardless of changes in employers or in work status. The AMA's plan would empower individuals to choose their health plans and give patients and their physicians more control over health care choices. Employers could continue to offer employment-based coverage, but employees would not be limited to health plans offered by their employer. Under this plan, the AMA contends that with a tax credit large enough to make coverage affordable and the ability to choose their own coverage, consumers would dramatically transform the individual and group health insurance markets. Health insurers would respond to the demands of the individual consumers and be more cautious about increasing premiums. Insurers would also tailor benefit packages and develop new forms of coverage to better match the preferences of individuals and families. The AMA also supports the development of new health insurance markets through legislative and regulatory changes to foster a wide area of high-quality, affordable health plans.

Both Democrats and Republicans are proposing health care plans with the Democratic plans relying on "play or pay" employer mandate to move toward universal coverage, requiring businesses to either offer workers insurance or pay a tax (Table 6). Historically, this has been the favorite approach for Democrats, until Clinton switched plans to pursue the more ambitious model of managed care competition. The reemergence of "pay or play" is a testament to the enduring political appeal of building on the status quo of employer-sponsored insurance, which has been a cornerstone of the US health care system since the 1940s and is now covering about 164.4 million non-elderly Americans (56). Democrats plan to finance universal coverage through employer payments rather than creating a publicly funded system that would require new broad-based taxes, which may in fact expand governmental authority, thus igniting substantial controversy and opposition from businesses that do not currently insure their workers. However, some current plans seek to exempt some small businesses from the mandate and also provide tax credit to small businesses that chose to offer insurance. Under the Democratic plans, even though private insurance is retained, their regulation is extended to ensure universal access, regardless of health status.

Republican plans do not propose the establishment of any major new federal insurance program or the adoption of any new employer or individual man- 
Table 6. Key elements of leading Republican and Democratic plans.

\begin{tabular}{|c|c|c|}
\hline & REPUBLICAN PLANS & DEMOCRATIC PLANS \\
\hline Employer mandate & $\begin{array}{l}\text { Changes in tax policy (new income tax } \\
\text { exclusions or credits) to improve access, } \\
\text { control costs, and provide incentives for } \\
\text { purchasing insurance outside the workplace. }\end{array}$ & $\begin{array}{l}\text { Employer mandate requiring businesses to either } \\
\text { offer workers insurance or pay a tax (some plans } \\
\text { exempt small businesses). }\end{array}$ \\
\hline Individual mandate & $\begin{array}{l}\text { No: } \\
\text { Expands coverage through tax code reform } \\
\text { and individual health savings accounts. }\end{array}$ & $\begin{array}{l}\text { Yes: } \\
\text { Most plans have individual mandate requiring all } \\
\text { Americans to have insurance, except for one plan, } \\
\text { which mandates only for children. }\end{array}$ \\
\hline Regulation and Universal Coverage & $\begin{array}{l}\text { A. Deregulation of insurance markets. } \\
\text { B. Creation of federal-state partnerships to } \\
\text { develop state-specific solutions. } \\
\text { C. Redirection of existing public subsidies to } \\
\text { help low-income Americans to buy private } \\
\text { insurance. }\end{array}$ & $\begin{array}{l}\text { A. Regulation of private insurance companies to } \\
\text { ensure universal access to coverage. } \\
\text { B. Establishment of new insurance purchasing } \\
\text { pools for businesses and individuals. } \\
\text { C. Government subsidies for individuals to } \\
\text { purchase insurance, varied according to income. } \\
\text { D. Creation of a new public insurance plan as an } \\
\text { additional option. } \\
\text { E. Financing largely from rollback of tax cuts for } \\
\text { high-income families. } \\
\text { F. Provisions designed to reassure insured } \\
\text { Americans that they can keep their current } \\
\text { coverage and have more choices. }\end{array}$ \\
\hline Expanding Information Technology & $\begin{array}{l}\text { Increased investments in health information } \\
\text { technology. }\end{array}$ & $\begin{array}{l}\text { Increased investments in health information } \\
\text { technology. }\end{array}$ \\
\hline Medical Malpractice & $\begin{array}{l}\text { A. Reforming medical malpractice by } \\
\text { restricting frivolous lawsuits. } \\
\text { B. Limiting pain and suffering awards. }\end{array}$ & $\begin{array}{l}\text { A. Including mandatory sanctions for frivolous } \\
\text { claims. } \\
\text { B. Including stopping insurer rate gouging. }\end{array}$ \\
\hline Expansion of Medicaid and SCHIP & $\begin{array}{l}\text { No expansion - but encourages state } \\
\text { innovations. }\end{array}$ & $\begin{array}{l}\text { Expansion of Medicaid and SCHIP to cover more } \\
\text { low-income Americans. }\end{array}$ \\
\hline Controlling Drug Prices & $\begin{array}{l}\text { A. Lowering drug costs by streamlining FDA } \\
\text { approval process. } \\
\text { B. Possibility of reimportation. }\end{array}$ & $\begin{array}{l}\text { A. By developing generic drugs. } \\
\text { B. By lowering drug costs by Medicare } \\
\text { negotiations } \\
\text { C. By monitoring doctor-drug maker ties. } \\
\text { D. By permitting reimportation from Canada and } \\
\text { from developing countries. }\end{array}$ \\
\hline Disease Management & $\begin{array}{l}\text { By promoting disease prevention and chronic } \\
\text { care. }\end{array}$ & $\begin{array}{l}\text { By promoting disease prevention and chronic } \\
\text { care. }\end{array}$ \\
\hline $\begin{array}{l}\text { Reform Provider Reimbursement to } \\
\text { Encourage Care Coordination. }\end{array}$ & $\begin{array}{l}\text { Yes } \\
\text { Dealing with costs - through multiple means. }\end{array}$ & $\begin{array}{l}\text { Yes } \\
\text { Dealing with costs - through multiple means. }\end{array}$ \\
\hline Evidence-Based Medicine & $\begin{array}{l}\text { Improve quality and promote evidence-based } \\
\text { medicine. }\end{array}$ & $\begin{array}{l}\text { Improve quality and promote evidence-based } \\
\text { medicine. }\end{array}$ \\
\hline
\end{tabular}


dates. Rather, their focus is on decentralized, marketoriented reforms rather than on achieving universal coverage. However, in a commentary, Ponnuru (64) stated that Republicans have quietly devised a radical way to reform health care, which essentially makes the Democrats look conservative. He claims that Republicans want to make a break with more than 6 decades of government policy and propose radical changes in the health care system. It appears that most Republicans have come to believe that our health care system is dysfunctional because it is employer-based and that this dysfunction has to be attacked at the root. Consequently, everything people dislike based on the Republican view about our system results from the tax break for employer coverage, which essentially makes costs rise, since people are less careful when they are not paying out of pocket. In his State of the Union address in 2007, President Bush proposed letting people buy their own insurance and qualify for the tax break just like their employers. This plan, it is estimated would help 7 million people who do not have insurance to get it and also offers individuals more control over their health care, letting them keep their policies even when they switch their jobs. The major disadvantage of this plan is that a lot of people would buy cheap insurance policies that cover only emergencies, while paying for routine care out of pocket, thus reducing some types of care, specifically interventional pain management. These plans have been criticized by liberal health experts who worry that they would cause the employer-based system to unravel more and the federal government to pay more for health care than any other insurance. Employers and health insurance companies who serve them are on the front lines of the struggle with the enormous problems of the costs and quality of health care in the United States (50).

\section{State Initiatives}

State-based health care reform varies from state to state. Maine, Massachusetts, and Vermont have enacted legislation to expand health insurance coverage. Governors in California, Illinois, Maryland, and Pennsylvania have put forth proposals and still others, including New York, are considering doing so (65). Most of the enacted reforms are primarily designed to improve health insurance coverage, but they also have additional features aiming at controlling costs or improving quality. Health care expenditures per capita vary from $\$ 3,972$ in Utah in 2004 to $\$ 6,683$ in Massa- chusetts $-70 \%$ higher than in Utah (65). In addition, the Commonwealth Fund Commission's State scoreboard found a two- to threefold or greater spread from top to bottom-ranked states on 32 indicators across 5 dimensions of health system performance which included access, quality, potentially avoidable use of hospitals and costs of care, equity, and ability to lead healthy lives (65). Overall, there is a strong correlation between state ranking on access and state ranking on quality. However, personal health spending per capita does not appear to have any relationship with mortality. In addition, there is an inverse relationship between states spending more on personal health care and states rankings on quality of care. Thus, states are embarking on not only an expansion of coverage but also on improving quality and reducing the costs. Massachusetts established the Health care Quality and Cost Council to develop and coordinate the implementation of policies and practices to lower or contain the growth in health care costs while improving the quality of care. Vermont combined its reform proposal with a chronic care improvement initiative. Maine established the Maine Quality Forum charged with promoting best practices, collecting and publishing comparative quality data, promoting electronic technology, and promoting healthy lifestyles (65). Vermont's new Health Reform Program, enacted under a Republican governor in a state with a Democratically-controlled legislature, is described to serve as an intriguing approach to resolving political differences in health care $(66,67)$.

While some states are progressing and some are not, over 20 years ago, in the Pennsylvania Health Care Cost Containment Councils' enabling legislation of 1986, the Pennsylvania general assembly cited "a major crisis because of the continuing escalation of costs for health care services" (68). An October 2007 report illustrated the bleak picture of the health care crisis in Pennsylvania. The report demonstrated that the crisis, continuing at unsustainable levels, still looms large in Pennsylvania just as it does in the rest of the nation. However, a report from Massachusetts (69) shows that recently enacted reform legislation is working, with the citizens of the Commonwealth of Massachusetts obtaining better coverage from all employers and also from firms employing 3 to 50 workers.

California, with its new reform proposal, is proposing to cover the uninsured and provide universal coverage (70). 


\section{Conclusion}

As veteran reformer Joseph A. Califano, Jr., has described, the American health care system is sick and needs "radical surgery" - now more than ever - as caretakers, the public at large, and the government continue to misdiagnose and mismanage health care. Health care expenditures have increased more rapidly than those for other goods and services in the United States and health care in other countries. The federal government has been a major force in health cost containment. However, these efforts have been only palliative rather than curative. Now we are in a state of flux in which corporate America, which is losing in the international marketplace, is demanding a fix to our health care system. If the government is unable to do it, there may be a day when private forces, namely, corporate America, may take over and reform health care itself. However, neither governmental nor privatized approaches are uniformly effective in maximizing the potential and actual benefits of health care because neither can work independently of the other. Universal health care is not a universal solution.

This manuscript described health care systems and costs not only in the United States but in several other countries. While the United States is looking for modernization or universal health care coverage, the most well-known national health system of Britain is going through a troubled transformation and the problems do not stop with Britain; almost all countries are still facing problems to a variable extent. A statistical comparison always makes the US health care look worse than it is. However, such complications do not resolve the problems neither for the United States nor for other countries; it only provides feel-good criteria for political players and feel-bad criteria for the rest of America.

In this manuscript, we reviewed various proposals to fix American health care, but health care in America is not just a commodity to be fixed. It involves hundreds of millions of lives.

Yes, American health care is the poster child of a sick health care system yet it provides satisfactory and the best health care for over $80 \%$ of Americans. Still, radical surgery is needed. However, this surgery should save the patient, not kill the patient. While there are many unproven solutions advanced, we should also remember the same was said about cost containment by Health Maintenance Organizations (HMOs), Diagnosis-Related Groups (DRGs), and the Sustainable Growth Rate (SGR). Now we also have the regulatory burden, which undoubtedly has saved American medicine, yet, at times, hundreds of billions of dollars are spent for unnecessary regulation, practice management costs, and administrative costs.

At times, health care reform may also depend on the messenger. While Hillary Clinton's old and new health care proposals face stiff opposition, her plan as part of her campaign for the democratic presidential nomination, is similar in some ways to one proposed by the Mayo Clinic's Health Policy Center. Both plans would cover the millions of Americans who have no health insurance (71). To cover the uninsured, both the Clinton and the Mayo proposals contain a provision known as "individual mandate," which would require every American to purchase health insurance, and both plans call for subsidies for those who cannot afford the insurance premium. Further, both plans provide the health care through private insurers, though heavily regulated. Thus, universal health care is not a new idea. It has been proposed by several presidents, going back as far as Woodrow Wilson. However, none of these plans ever made it, but, similarities between various opposing groups may lead to some type of universal health coverage in the future.

To save American health care, first we all need to get along and not pit one against the other. We all understand that there is a one size pie and each one of us wants a larger bite of it. To reform health care, provide universal health care, and to preserve it into the future, all sectors of health care must sacrifice and come together.

The problem is not in the national health care system, universal coverage, or private health insurance alone. All of the systems have inherent deficiencies. If we arrive at mathematical equality, reducing the abuse and bureaucracy will put us at the same level as other countries in health care costs. However, proponents of regulation state that it will increase US health care costs by $20 \%$ or so rather than reduce it. In these days of evidence based medicine and accountability, it is ironic that there is neither accountability nor evidence of effectiveness of any of the health care systems in force at the present time.

Whatever system is implemented, with universal coverage and tightening of regulations, cost savings tend to take a very high priority. However, access will be redefined for primary care and emergency services with other services such as interventional pain management being defined as boutique services. 


\section{Acknowledgments}

The author wishes to thank Tonie D. Hatton and

Diane E. Neihoff, transcriptionists, and Vidyasagar

Pampati, MSc, for their assistance in the preparation

of this manuscript.

\section{References}

1. Califano JA. Radical Surgery What's Next for America's Health Care. Times Books, New York, 1994.

2. Proposed Legislation: The Health Security Act of 1993. US Government Printing Office, House Document, Washington, DC, 1993, 103-174.

3. Hacker JS. Health care for America: A proposal for guaranteed, affordable health care for all Americans building on Medicare and employment-based insurance. The Economic Policy Institute EPI Briefing Paper \#180 January 11, 2007.

4. Orszag PR, Ellis P. The challenge of rising health care costs - A view from the Congressional Budget Office. N Engl J Med 2007; 357:1793-1795.

5. Orszag PR, Ellis P. Addressing rising health care costs - A view from the Congressional Budget Office. N Engl J Med 2007; 357:1885-1887.

6. Hacker JS. Healing our Sicko health care system. N Engl J Med 2007; 357:733735.

7. Poisal JA, Truffer C, Smith S, Sisko A, Cowan C, Keehan S, Dickensheets B, National Health Expenditure Accounts Projections Team. Health spending projections through 2016: Modest changes obscure Part D's impact. Health Aff (Millwood) 2007; 26:w242-w253.

8. McKinsey Global Institute. A Framework to Guide Health Care System Reform. October 2006.

9. 2007 Annual Report of the Boards of Trustees of the Federal Hospital Insurance and Federal Supplementary Medical Insurance Trust Funds. Washington, D.C., April 23, 2007. http://www.cms. hhs.gov/ReportsTrustFunds/downloads/tr2007.pdf

10. The Medicare Prescription Drug, Improvement, and Modernization Act of 2003, P.L. 108-173, December 8, 2003.

11. McKinsey Global Institute. Accounting for the Cost of Health Care in the United States. January 2007.

12. An Overview of the US Health Care Sys- tem Chart Book. Centers for Medicare and Medicaid Services and Office of the Assistant Secretary for Planning and Evaluation. January 31, 2007. www. cms.hhs.gov/TheChartSeries/downloads/Chartbook_2007_pdf.pdf. Accessed 11-30-2007.

13. Organisation for Economic Co-operation and Development. Health at $a$ Glance 2007 - OECD Indicators. November 13, 2007. www.oecd.org/health/ healthataglance

14. Manchikanti L, Hirsch JA. Issues in health care: Interventional pain management at the crossroads. Health policy update. Pain Physician 2007; 10:261-284

15. CMS Office of the Actuary, 2007.

16. Department of Health and Human Services, Centers for Medicare \& Medicaid Services. 42 CFR Parts 411 and 424. Medicare Program; Physicians' Referrals to Health Care Entities with Which They Have Financial Relationships (Phase III); Final Rule. 72 Federal Register 51,012-51,099, Wednesday, September 5, 2007.

17. US Department of Health and Human Services, Office of the Inspector General, Financial Arrangements Between Physicians and Health Care Businesses, OAl-12-88-01410, May 1989.

18. Manchikanti L, McMahon EB. Physician refer thyself: Is Stark II, Phase III the final voyage? Health Policy Update. Pain Physician 2007; 10:725-741.

19. The Medicare and Medicaid Patient Protection Act of 1987, as amended, 42 U.S.C. \$1320a-7b (the "Antikickback Statute”), P.L. 100-93, January 23, 1989.

20. Dutton P. France's model health care system. Boston Globe, August 11, 2007. http://www.boston.com/news/ globe/editorial opinion/oped/articles/2007/08/11/frances_model_ healthcare_system

21. Knottnerus JA, Ten Velden GH. Dutch doctors and their patients -- effects of health care reform in The Netherlands.
N Engl J Med 2007; 357:2424-2426.

22. Henley J. French health service on verge of collapse, says commission. The Guardian, London, England, January $24,2004$.

23. Dorozynski A. France abandons fines to control health costs. BMJ 1999; 318:76.

24. Conover CJ. Health care regulation: A $\$ 169$ billion hidden treatment. CATO Institute, Policy Analysis No. 527, October 4, 2004. Washington, DC.

25. Schoen C, Osburn R, Doty MM, Biship M, Peugh J, Murukutla N. Toward higher-performance health systems: adults' health care experiences in seven countries, 2007. Health Aff 2007; 26:w717w734.

26. Starfield B, Shi L, Macinko J. Contribution of primary care to health systems and health. Milbank Quarterly 2005; 83:457-502.

27. Beal AC, Doty MM, Hernandez SE, Shea KK, Davis K. Closing the Divide: How Medical Homes Promote Equity in Health Care: Results from the Commonwealth Fund 2006 Health Care Quality Survey. Vol. 62 Commonwealth Fund, New York, June 27, 2007. www.commonwealthfund.org/publications/publications_show.htm?doc_id=506814

28. Schoenbaum SC, Abrams MK. No Place Like Home, 19 December 2006, www. commonwealthfund.org/aboutus/ aboutus_show.htm?doc_id=434064

29. Organisation for Economic Co-operation and Development, "OECD Health Data: Specialists Outnumber GPs in Most OECD Countries," 18 July 2007, www.oecd.org/document/10/ 0,3343,en_2649_37407_38976778_1_ 1_1_37407,00.html

30. Schoen C, Osborn R, Huynh PT, Doty M, Davis K, Zapert K, Peugh J. Primary care and health system performance: Adults' experiences in five countries. Health Aff 2004; w487-w503.

31. France tackles heat emergency. CNN. comWORLD Thursday, August 14, 2003. www.cnn.com/2003/WORLD/ 
Europe/08/14/paris.heatwave

32. France heat wave death toll set at 14,802. USA Today. September 25, 2003. www.usatoday.com/weather/ news/2003-09-25-france-heat_x.htm

33. Bhattacharya S. European heatwave caused 35,000 deaths. October 10, 2003. http://environment.newscientist.com/channel/earth/climatechange/dn4259

34. Heatwave sweeps through Europe, leaving at least 23 dead. Europe News, July 21, 2006. http://news.monstersandcritics.com/europe/news/article 1182922.php

35. Nowak D. Doctors on strike - The crisis in German health care delivery. $N$ Engl J Med 2006; 355:1520-1522.

36. Kassirer JP. Managed care and the morality of the marketplace. $N$ Engl I Med 1995; 333:50-52.

37. Cooper-Mahkorn D. German doctors strike against health budget cuts. $B M J$ 1999; 318:76.

38. Enthoven AC, van de Ven WP. Going Dutch - Managed-competition health insurance in The Netherlands. N Engl J Med 2007; 357:2421-2423.

39. Enthoven AC. Consumer-choice health plan. N Engl J Med 1978; 298:650-658.

40. Quality, affordable health care for all: Moving beyond the employer-based health insurance system. Washington DC, Committee for Economic Development, October 15, 2007.

41. Klein R. The troubled transformation of Britain's National Health Service. $N$ Engl J Med 2006; 355:409-415.

42. Department of Health. Departmental report 2005. London, Stationery Office, 2005 (Series no. CM 6524).

43. Klein R. The new politics of the NHS: From creation to reinvention, 5 th ed. Radcliffe Medical Press, Oxford, England, 2006.

44. Dalrymple T. Health of the state: Doctors, patients, and Michael Moore. $\mathrm{Na}$ tional Review 2007; 14:32-34.

45. Gratzer D. The ugly truth about Canadian health care. City Journal, Washington DC, Summer 2007.

46. Catlin A, Cowan C, Heffler S, Washington B, National Health Expenditure Accounts Team. National health spending in 2005: The slowdown continues. Health Aff (Millwood) 2007; 26:142153.

47. Robinson JC. The commercial health insurance industry in an era of eroding employer coverage. Health Aff (Mill- wood) 2006; 25:1475-1486.

48. Congressional Budget Office Economic and Budget Issue Brief. The sustainable growth rate formula for setting Medicare's physician payment rates. September 6, 2006.

49. United States Government Accountability Office. Report to the Chairman, Committee on Finance, US Senate. Steps Taken to Improve Federal Oversight but Other Actions Needed to Sustain Efforts. Medicaid Financial Management. GAO-06-705, June 2006.

50. Blumenthal D. Employer-sponsored insurance - riding the health care tiger. $N$ Engl J Med 2006; 355:195-202.

51. Managing health care costs in a new era: 10th annual business group on health/Watson Wyatt survey report, 2005. Washington DC, Watson Wyatt Worldwide, 2005. www.watsonwyatt. $\mathrm{com} / \mathrm{research} /$ resrender.asp?id=w821\&page $=1$

52. Health Benefit Cost Slows for a Third Year, Rising Just $6.1 \%$ in 2005 , United States. Press release of Mercer Human Resource Consulting, New York, November 21, 2005. www.mercerhr.com/ pressrelease/details.jhtml/dynamic/ idContent/1202305

53. Cowan CA, Hartman MB. Financing health care: Businesses, households, and governments, 1987 - 2003. Baltimore, Centers for Medicare \& Medicaid Services, July 2005 (Health Care Financing Review Web exclusive). www. cms.hhs.gov/apps/review/web_exclusives/cowan.pdf

54. The Henry J. Kaiser Family Foundation/ Health Research and Educational Trust Survey of Employer-Sponsored Health Benefits, 1999 to 2005. September, 2005 www.kff.org/insurance/7315/sections/upload/7316.pdf

55. Appleby J, Silke Carty S. Ailing GM looks to scale back generous health benefits. USA Today, June 23, 2005:B1.

56. Oberlander J. Presidential politics and the resurgence of health care reform. $N$ Engl J Med 2007; 357:2101-2104.

57. Blendon RJ, Hunt K, Benson JM, Fleischfreeser C, Buhr T. Understanding the American public's health priorities: A 2006 perspective. Health Aff (Millwood) 2006; 25:w508-515.

58. Blendon RJ. One academic's perspective on the role of health affairs. Health Aff (Millwood) 2007; 26:1531-1533.

59. Kaiser Health Tracking Poll: Election 2008. The Henry J. Kaiser Family Foun- dation, Issue 3, August 2007. www.kff. org/kaiserpolls/upload/7691.pdf

60. Page S, Risser W. Ware not the only root of anxiety. USA Today. December 5, 2007:1A.

61. Committee for Economic Development. Quality, Affordable Health Care for All: Moving Beyond the Employer-Based Health-Insurance System. A Statement by the Research and Policy Committee of the Committee for Economic Development. Washington, DC. w w w . ced.org/docs/report/report_health care200710.pdf

62. Rittenhouse DR, Grumbach K, O'Neil EH, Dower C, Bindman A. Physician organization and care management in California: From cottage to Kaiser. Health Aff (Millwood) 2004; 23:51-62.

63. Palmisano DJ, Emmons DW, Wozniak GD. Expanding insurance coverage through tax credits, consumer choice, and market enhancements: The American Medical Association proposal for health insurance reform. JAMA 2004; 291:2237-2242.

64. Ponnuru R. Sneak attack. Republicans have quietly devised a radical way to reform health care. It makes the Democrats look conservative. Time, November 19, 2007.

65. Davis D, Schoen C. State health system performance and state health reform. Health Aff 2007; 26:w664-w666.

66. Thorp KE. Vermont's catamount health: A roadmap for health care reform? Health Aff 2007; 26:w703-w705.

67. Maxwell J. Comprehensive health care reform in Vermont: A conversation with Governor Jim Douglas. Health Aff 2007; 26:w697-w702.

68. Critical Condition: The State of the Health Care in Pennsylvania. Pennsylvania Health Care Cost Containment Council (PHC4). October 2007. www.phc4.org/reports/sos/07/docs/ sos2007report.pdf

69. Gabel JR, Whitmore H, Pickreign J. Report from Massachusetts: Employers largely support health care reform, and few signs of crowd-out appear. Health Affairs Web Exclusive, November 14, 2007.

70. Halvorson GC, Crosson FJ, Zatkin S. A proposal to cover the uninsured in California. Health Aff 2007; 26:w80-w91.

71. Medical Practice Management News. Clinton, Mayo health plan similar. J Med Pract Manage 2007; 23:137, 140 